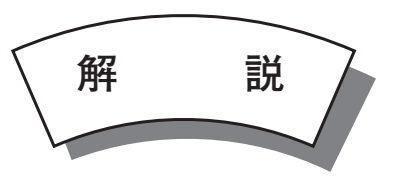

\title{
近年の材料系学術論文にみる溶射および関連技術の動向 \\ Recent Trends of Thermal Spray and Related Technologies Reviewed from Material Science Journal Articles
}

Key Words: Thermal Spray, Review, Journal Article

\section{1. はじめに}

溶射と呼ばれる表面改質方法/プロセスは現代の工業生 産活動に直結する実務手段のひとつであり、工学分野の中 でも特に生産手段の要素技術として不可欠なものと考えら れている。いま、溶射工学という分野が存在するかどうか の議論はさておき、本分野で学際的に既存の学問分野から の接近を図ろうとする活動がさかんなことは周知である。 溶射の科学技術はわが国が必ずしも先導しているものでは なく、インパクトファクターのある英文誌などの外国語論 文であることはこれまでのところ否定できない。しかし、 科学技術成果は国内の和文誌でその萌芽が発信されている ことも事実である。特定の分野に限定して現状と今後の課 題を抽出しようとする努力はそれぞれの分野ごとに一定の 周期でなされているが、わが国における溶射科学技術の变
遷を捉えて 10 年単位でまとめた報告はこれまでのところほ とんど見あたらない。

本稿では、西暦 2000 年から 2009 年にいたる 10 年間の溶 射表面改質とその周辺技術の趨勢を、主として材料系の学 協会機関誌、論文集に掲載された内容を紹介することでそ れらの動向を把握することを試みた。また、これらの開示 情報に対し、筆者が課題として認識している溶射の要素技 術の内容についても二、三考察した。

\section{2. 論文・解説記事の量的把握}

2000 年から 2009 年に至る 10 年間の、主に材料系学協会 機関紙/論文誌に掲載された溶射とその関連科学技術を対 象とした解説、原著論文をとりあげた。誌名はTable 1 に 示す 13 誌である。本稿ではこれら誌の目次記事を基本に して筆者が溶射に関係すると判断したものを抽出した。総

Table 1 Academic journals and societies covered.

学術誌名

溶射

Materials Transactions

高温学会誌

材料

日本機械学会論文集

日本金属学会誌

溶接学会論文集

まてりあ

表面技術

日本ガスタービン学会誌

材料と環境

Journal of Ceramic Society of Japan

鉄と鋼
学協会名

(一般社) 日本溶射協会

(社)日本鋳造工学会、銅及び銅合金技術研究会、

(社)日本溶射協会、ナノ学会、(社軽金属学会、

(社)日本金属学会、(社)日本熱処理技術協会、(社)日本塑性加工学会,

(社)日本非破壊検查協会、(社)資源・素材学会、日本熱電学会

(社)高温学会

(社)日本材料学会

(社)日本機械学会

(社)日本金属学会

(社)溶接学会

(社)日本金属学会

(社)表面技術協会

(社)日本ガスタービン学会

(社)腐食防食協会

(社)日本セラミックス協会

(社)日本鉄鋼協会

*トーカロ株式会社＼cjkstart溶射技術開発研究所（广 674-0093 明石市二見町南二見 14-3）

Thermal Spraying Technology R\&D Laboratories, TOCALO Co., Ltd. (14-3, Minamifutami, Futami-cho,Akashi, Hyogo, 674-0093, Japan) 
高 温 学 会 誌 第 36 巻 第 6 号 (2010 年 11 月)

Table 2 Annually number of published contributions.

\begin{tabular}{|l|c|c|c|c|c|c|c|c|c|c|}
\hline & 2000 & 2001 & 2002 & 2003 & 2004 & 2005 & 2006 & 2007 & 2008 & 2009 \\
\hline 溶射 & 10 & 9 & 8 & 7 & 5 & 13 & 8 & 9 & 8 & 7 \\
\hline Materials Transactions & N/A & 6 & 2 & 6 & 3 & 10 & 25 & 7 & 3 & 2 \\
\hline 高温学会誌 & 8 & 9 & 9 & 9 & 7 & 4 & 5 & 4 & 1 & 5 \\
\hline 材料 & 5 & 1 & 1 & 4 & 8 & 1 & 3 & 3 & 6 & 5 \\
\hline 日本機械学会論文集, A, B, C 編 & 6 & 2 & 2 & 0 & 2 & 0 & 5 & 2 & 3 & 7 \\
\hline 日本金属学会誌 & 1 & 6 & 4 & 0 & 4 & 2 & 2 & 4 & 2 & 1 \\
\hline 溶接学会論文集 & 1 & 2 & 5 & 3 & 2 & 3 & 4 & 0 & 0 & 0 \\
\hline まてりあ & 0 & 9 & 1 & 0 & 0 & 0 & 0 & 2 & 0 & 0 \\
\hline 表面技術 & 1 & 1 & 0 & 0 & 0 & 1 & 0 & 0 & 7 & 0 \\
\hline 日本ガスタービン学会誌 & 0 & 0 & 7 & 1 & 0 & 0 & 0 & 1 & 0 & 1 \\
\hline 材料と環境 & 0 & 2 & 1 & 1 & 0 & 1 & 0 & 0 & 0 & 1 \\
\hline Journal of Ceramic Society of Japan & 0 & 0 & 0 & 0 & 1 & 0 & 1 & 1 & 0 & 2 \\
\hline 鉄と鋼 & 1 & 0 & 0 & 0 & 0 & 1 & 0 & 0 & 0 & 1 \\
\hline \multicolumn{1}{|c|}{ 367構成比 \% } & 33 & 47 & 40 & 31 & 32 & 36 & 53 & 33 & 30 & 32 \\
\hline & 8.99 & 12.8 & 10.9 & 8.45 & 8.72 & 9.81 & 14.4 & 8.99 & 8.17 & 8.72 \\
\hline
\end{tabular}

編数は 367 であった。但しこの数值は公刊されたこの分野 の論文のすべてを網羅するものではない。「溶射」誌は本 分野の専門的な学協会の機関誌であるので揭載数が最も多 い。基本的に和文誌であるが、Materials Transactions, Journal of Ceramic Society of Japan の 2 誌は英文誌である。 Materials Transactions 誌は現在、日本金属学会、日本溶射協会をはじ めとする 11 学協会の共同刊行である。また、学術誌/年度 ごとの編数分布を Table 2 に示した。変動はややあるもの の、概して変化が少なく、漸増、漸減の傾向は読み取れない。

\section{3. 論文・解説記事の内容的把握}

溶射は学際的分野を対象とする工学領域と考えられてい る。したがって論文・解説の内容を分類するには一義的で はなく種々の考え方をとることが必要であり、分類に工夫 を要する。ここでは直接的な分類手法の例として、分野 1 : 皮膜 / 改質層 / 表面の創製、分野 2 : 皮膜 / 改質層 / 材料の 加工処理方法 (プロセッシング)、分野 $3:$ 形成皮膜材料特 性の調査・評価方法、分野 4 : 改質層が提供すると考元ら れる表面特性・機能評価、分野 5 : 皮膜/改質層を創製す るために用いられるプロセス機器、分野 6 ：溶射現象の測 定・診断手法、現象の観察・モデル化・シミュレーション、 分野 7 : 皮膜/改質層の作製にかかる前後処理、分野 8 : 工 業的応用事例、分野 9 : 総説・解説・その他、の範疇によっ て溶射技術の動向・内容を把握することを試みた。367 編 の文献をこれらの分野分類で整理したものを Table 3 に示 す。材料系学術誌の性格から予想されると㧍り、溶射皮膜 とその関連特性の評価・調査を対象とするものが $34 \%$ を占 めた。また、解説記事が少なからず投稿されており、調査
全文献に占める比率は $16 \%$ を超えた。他の工学領域のデー 夕を筆者はいまのところ持ちあわせないが、この数值をど う解釈すべきであろうか。今後の判断に委ねる。

\section{1 分野 1 : 皮膜 / 改質層 / 表面の創製}

溶射は基材が本来保有しない材料特性をその表面に付与 することができる有効な手段である、との認識からまずこ の分類カテゴリーをとりあげた。53 編の内容からは現在広 く実用になっている材料、表面を対象とし、実用の材料学 的根拠を明らかにすることを試みるものを期待したが、こ れらを満足させる文献はほとんどみられなかった。未実用 領域にある窒化物、表面の窒化処理 ${ }^{1-77}$ 、チタン酸化物を用

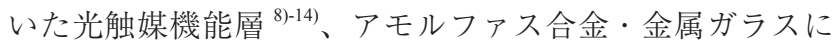
関するもの ${ }^{15)-199}$ 、それぞれ 7, 7, 5 編であった。溶射により 窒化物を生成して新材料を創製する試みは産業界からも期 待があったが、実用域に達した成果の開示はないようであ る。また、金属ガラスはバルク材で磁性、強度など様々な 新しい特性が得られることが明らかになっているが、実用 表面改質層として供用されているという知見は今回の範囲 では開示されていない。そのほか、ナノ粒子材料を用いた 粉末材料の皮膜特性発現解明 ${ }^{20)-23)}$ 、七ラミックス・金属 樹脂複合材創製 24-26)、傾斜組成材料作製 27), 28)、ダイヤモン ド合成 ${ }^{29,}, 30$ )、電熱爆発高温高速流を用いた非酸化物材作製 31), 32) は各 4, 3, 2, 2, 2 編であった。さらに、複合材として、 フッ化カーボン - $\mathrm{Al}$ 複合材 2 編 ${ }^{33)}$, 40)、鋳鉄表面への WC 粒 子打込み ${ }^{34)} 、 \mathrm{SiC}$ 瀻維強化 $\mathrm{Ti}$ 基材料 ${ }^{35)}$, 36) 、セラミック表面 のアルミニウム化 ${ }^{377} 、 \mathrm{SiO}_{2} / \mathrm{Al}-\mathrm{Mg}{ }^{38)}$ 、廃 PET 材表面の金属 化 ${ }^{39)}$ 、カーボンナノチューブーポリエチレン複合材 ${ }^{41}$ が 
Table 3 Contributions for each category

\begin{tabular}{|l|c|c|c|c|c|c|c|c|c|c|}
\hline & 投稿数 & 分野 1 & 分野 2 & 分野 3 & 分野 4 & 分野 5 & 分野 6 & 分野 7 & 分野 8 & 分野 9 \\
\hline 溶射 & 84 & 14 & 7 & 6 & 25 & 3 & 6 & 13 & 2 & 8 \\
\hline Materials Transactions & 64 & 9 & 8 & 3 & 29 & 1 & 7 & 9 & 0 & 0 \\
\hline 高温学会誌 & 61 & 13 & 5 & 0 & 17 & 4 & 5 & 9 & 1 & 7 \\
\hline 材料 & 37 & 0 & 3 & 8 & 21 & 0 & 0 & 0 & 5 & 0 \\
\hline 日本機械学会論文集、A, B, C 編 & 30 & 4 & 1 & 5 & 14 & 0 & 2 & 1 & 1 & 1 \\
\hline 日本金属学会誌 & 26 & 7 & 2 & 0 & 8 & 0 & 1 & 4 & 4 & 0 \\
\hline 溶接学会論文集 & 20 & 6 & 2 & 1 & 3 & 3 & 5 & 0 & 0 & 0 \\
\hline まてりあ & 12 & 0 & 0 & 0 & 0 & 0 & 0 & 0 & 0 & 12 \\
\hline 表面技術 & 10 & 0 & 0 & 0 & 0 & 0 & 0 & 0 & 0 & 10 \\
\hline 日本ガスタービン学会誌 & 10 & 0 & 0 & 0 & 1 & 0 & 0 & 0 & 0 & 9 \\
\hline 材料と環境 & 6 & 0 & 0 & 0 & 5 & 1 & 0 & 0 & 0 & 0 \\
\hline Journal of Ceramic Society of Japan & 5 & 3 & 0 & 0 & 1 & 0 & 0 & 0 & 0 & 1 \\
\hline 鉄と鋼 & 3 & 0 & 0 & 0 & 3 & 0 & 0 & 0 & 0 & 0 \\
\hline \multicolumn{1}{|c|}{367 編 } & 367 & 56 & 28 & 23 & 127 & 12 & 26 & 36 & 13 & 48 \\
\hline & 100.5 & 15.3 & 7.63 & 6.25 & 34.6 & 3.26 & 7.08 & 9.81 & 3.54 & 13.1 \\
\hline
\end{tabular}

分野 1 : 皮膜 / 改質層 / 表面の創製、分野 2 : 皮膜 / 改質層 / 材料の加工処理方法（プロセッシング）、

分野 3 : 形成皮膜材料特性の調査・評価方法、分野 4 : 改質層が提供すると考えられる表面特性・機能評価、

分野 5: 皮膜/改質層を創生するために用いられるプロセス機器、

分野 6：溶射現象の測定・診断手法、現象の観察・モデル化・シミュレーション、

分野 7 : 皮膜/改質層の作製にかかる前後処理、分野 8: 工業的応用事例、分野 9 : 総説・解説・その他

ある。耐硫化腐食手段としての $\mathrm{Cr}-\mathrm{Fe}$ 皮膜 2 編 ${ }^{42)}$, 43)、導電 材皮膜 2 編 $\left(\mathrm{SrTiO}_{3}\right.$ 、ランタンシリケートイオン伝導体皮

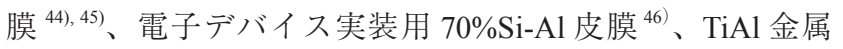
間化合物皮膜 ${ }^{47)}$ 、湿式光センサー材 ${ }^{48)}$ 、熱電材料 ${ }^{49)}$ 、MA 法 $\mathrm{Ni}$ 皮膜 ${ }^{50)}$ 、研削材用硬質 $\mathrm{TiAl}$ 皮膜 ${ }^{51)}$ 、エアロゾルデポ ジションによる緻密な $\mathrm{Y}_{2} \mathrm{O}_{3}$ 薄膜 ${ }^{52)} 、 \mathrm{TiO}_{2}$ 電極材 ${ }^{53)}$ などの 報告が見られた。一方、プロセスで見ると、大気圧プラズ マ、HVOF/HVAF がいずれも 7 編、高周波を含む反応性プ ラズマが 6 編。これに対し、レーザー、コールドスプレー はそれぞれ 1,2 編にとどまった。チタンを中心とする複合 材、金属間化合物材は皮膜化の道が明らかになっていない。 光触媒機能、金属ガラス機能発現溶射皮膜も同様である。

3.2 分野 2：皮膜 / 改質層 / 材料の加工処理方法（プロセッ シング）

28 編の内容を対象とした。皮膜や改質層の形成。作製 にはプロセスの最適化が必要である。工業材料として実用 化するにはその製造方法を効率化しなければならない。こ こではプロセッシングを溶射皮膜作製の一手法にとどまら ず、最適化をはかるため、作製の条件を検討する内容とし て捉えた。それらは、溶射熱源特性の調整・設定などに代

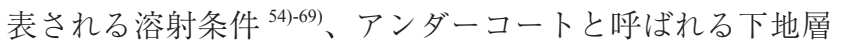

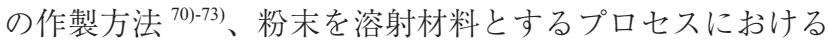

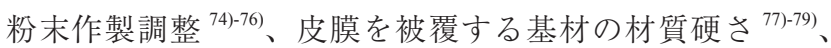

溶射装置方式 ${ }^{80,81)}$ 、がそれぞれ $16,4,3,3,2$ 編であった。溶 射条件の検討によって溶射皮膜の密着力や発現機能の向 上・最適化を志向しょうとする報告は皮膜性能への影響に は直接言及せず、原著論文としての格段の新規性、進歩性 はみられなかった。熱遮蔽皮膜（以下、TBC's）における 合金下地層は高温供用中の酸化進行によってトップコート と基材を接着する機能が低下することがわかっているの で、その機構についての観察や、酸化進行を抑制するため の施策について言及している。特に熱遮蔽皮膜におけるア ンダーコート層酸化抑制などの耐用寿命の向上に興味が向 けられている印象であった。

\section{3 分野 3 : 形成皮膜材料特性の調査・評価方法}

23 編の内容をとりあげた。まず、TBC's の特性把握を対

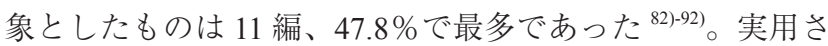
れている TBC's 特性の調査・評価に対しての留意が伺える。 ただし、ほとんどの研究者が試料として実験室的に作製し たものを調査・解析対象としていた。実運転したガスター ビン設備の実機翼部材から抽出して得た試料を対象とし、 たとえば実機供用中の、下地層とセラミック層界面近傍で 生成する下地層合金の酸化物 (TGO) 生成挙動を明らかにし た報告は見あたらなかった。発電用ガスタービン機器の純 国産メーカーは現在 1 社で、他は海外メーカーの技術仕様 を採用している現実の背景があることを示している。 
皮膜被覆した部材の残留応力の把握では、変形測定によ

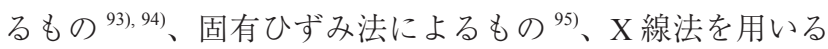
ときの諸問題 ${ }^{96)}$ 、が報告されている。皮膜の基材接合強度 に留意したものでは、密着力を円管基材横圧縮法 ${ }^{97)}$ 、ひず み計測による SUS304 皮膜の高温疲労過程観察 ${ }^{98)}$ 、基材局 所加熱による皮膜剥離挙動観察 ${ }^{99}$ 、 $\mathrm{AE}$ 法による皮膜剥離

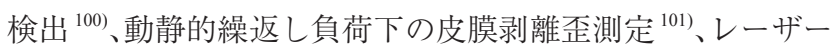
レンジファインダーによる溶射皮膜のはく離状態と 3 次元 位置の同時検出 ${ }^{102)}$ 、皮膜のスラリー摩耗予測 ${ }^{103)}$ 、溶射皮 膜の密着性評価手法における課題 ${ }^{104)}$ 、が提起されている。

\section{4 分野 4 : 改質層が提供する表面特性・機能評価}

小項目を上記のように記したが、どのように内容を取り 上げるかは少々議論を要するところである。この範疇で 125 編を抽出した。皮膜機能の属性から分類すると、研究 対象の多いものから、TBC's：26 編、主に炭化物サーメッ 卜溶射皮膜の耐水溶液腐食挙動：12 編、残留応力：11 編、 アルミナ等酸化物セラミック溶射皮膜の強度 : 11 編、皮膜 の耐疲労特性：10 編、炭化物サーメット溶射皮膜のその他 の特性:9 編、コールドスプレー: 5 編、生体適用皮膜 $: 8$ 編、 $\mathrm{Zn}-\mathrm{Al}$ 系犠牲防食皮膜: 6 編、溶射皮膜の微細構造観察: 5 編、 皮膜の耐キャビテーション壞食：4編、 Ti 酸化物の光触媒 特性 : 3 編、熱電・電導特性 : 3 編、工業廃材のリサイクル 3 編、耐プラズマ壊食 2 編、トライボロジ : 2 編、その他 6 編の計 125 編であった。

まず、TBC’sに関するものでは、熱時効、熱サイクル、 クリープ、熱疲労の因子で基材からの剥離挙動を扱ってい $3^{105), 106), 110), 112),(14), 119), 120), 128), 131)}$ 。酸化、硫化などの高温環境の

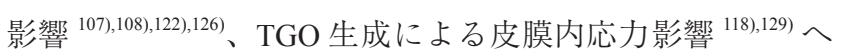
の言及がみられる。皮膜微細構造、下地層とセラミック層

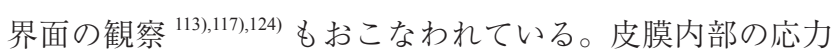
分散吸収を目的とした構造検討 ${ }^{115), 123)}$ 、 $\mathrm{Ni}$ 基合金基材と下 地層皮膜の相互拡散把握 ${ }^{109)}$ 、応力 - 歪挙動、破壊勒性など

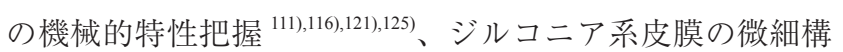
造と弾性係数 ${ }^{127)}$ 、皮膜組織変化からの高温曝露履歴推定 130)、が研究分野として捉えられている。

炭化物サーメット溶射皮膜の耐水溶液腐食挙動では、高 谷は皮膜化学成分と水溶液 $\mathrm{pH}$ の及ぼす影響を整理した 136)。竹田、新原らが $\mathrm{Na}_{2} \mathrm{SO}_{4}$ 水溶液中での挙動を系統的に 報告している ${ }^{132)-135),(37), 141), 143)}$ 。また、黒田、川喜多らは高速 ガス炎溶射法を用いて環境遮断性に優れた合金皮膜の検討

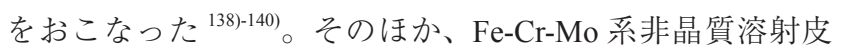
膜の耐食性が検討された ${ }^{142)}$ 。

残留応力については、応力の特性 ${ }^{144)}$ 、測定值 ${ }^{147) 、}$ 分 布解析 ${ }^{151}$ を論じたもの、ショットコーティング皮膜の例 148),149)、自溶合金皮膜での例 ${ }^{152), 153)}$ が示された。基材および 溶射プロセスにもとづく粒子衝突積層の形態から残留応力 の発生機構を論じたもの ${ }^{146), 154)}$ や、残留応力が発生する結
果生じる現象 ${ }^{145), 150)}$ についても議論があつた。

アルミナ等酸化物セラミック溶射皮膜の強度に関して は、荒巻らは残留応力制御から種々負荷に対する溶射構造

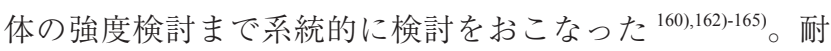
剥離性非破壊評価 ${ }^{155)}$ 、種々金属材料基材に被覆した皮膜 の転動環境などでの疲労強度評価 ${ }^{156), 158), 159), 161) 、 ア ル ミ ナ / ~}$ YAG 複合材の皮膜の構造制御 ${ }^{157)}$ が報じられている。

皮膜の耐疲労特性では、Co 基自溶合金皮膜の疲労 166),167),170)、酸化物皮膜の高温環境下での疲労 ${ }^{168), 169) 、 セ ラ ~}$ ミック溶射材の静・動的荷重下の歪み・剥離挙動 ${ }^{171)-174)}$ 、 WC-Co 皮膜の疲労亀裂進展特性 ${ }^{175)}$ の報告がある。

炭化物サーメット皮膜の特性評価では、 $\mathrm{Cr}_{3} \mathrm{C}_{2}-\mathrm{NiCr}$ 皮膜 の微細構造観察による検討 ${ }^{176), 178), 183)}$ 、WC-Co 皮膜の剥離強 度、表面損傷に及ぼす因子の検討 ${ }^{179)-181), 184) 、 W C-17 C o ~}$ 皮膜 $^{-1}$ の熱処理の影響 ${ }^{177)}$ のほか、WC-12Co 皮膜の切り欠き破壞 強度検討 ${ }^{182)}$ が報じられている。

これらのほか、コールドスプレーでは銅 ${ }^{185), 188)-190) 、 ア ル ~}$ ミニウム皮膜 ${ }^{186), 187)}$ に関する報文がある。生体材料関係で は傾斜機能付与溶射 ${ }^{191)}$ 、ハイドロキシアパタイト皮膜の 生体適合性 ${ }^{192)}$ 、同機械的強度 ${ }^{193), 197), 198)}$ 、同三次元構造観察 194)、Ti-Al-V材の機械的強度評価 ${ }^{195), 196)}$ が対象となっていた。

$\mathrm{Zn}-\mathrm{Al}$ 合金皮膜の犠牲防食特性は、6 編 ${ }^{199)-204)}$ 開示された。 特筆すべき内容はみとめられない。溶射皮膜の微細構造は

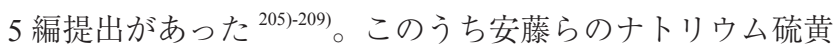
二次電池のアルミニウム合金製格納容器内面に対する環境 遮断構造・機能に関する検討 ${ }^{209)}$ は興味深い。

耐キャビテーション壊食では、耐久性を有する皮膜開発 をめざしたと考えられるものが 2 編 ${ }^{211), 213)}$ あるが、ほかの 2 編 ${ }^{210), 212)}$ は、溶射皮膜の構造強度評価の手段提案とみたほ うがよい。Ti 酸化物光触媒、熱電・電導特性に関するもの

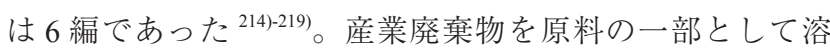
射材料を作製、機能皮膜開発を試みたものがあった 220)-222)。 耐プラズマ壊食性を取り上げたものでは、窒化アルミニウ ム/アルミナ複合材溶射皮膜 ${ }^{223)}$ 、酸化物セラミック溶射皮 膜の耐低温プラズマ壊食性の議論 ${ }^{224)}$ がある。トライボロ ジでは自動車用部材への適用を目的に高 $\mathrm{Si}-\mathrm{Al}$ 合金 ${ }^{225)}$ のほ か、フッ素樹脂 - 金属複合材の検討事例 ${ }^{226)}$ があった。そ の他 6 編 ${ }^{227)-232)}$ の検討報告を認めた。

3.5 分野 5 : 皮膜/改質層を創製するために用いられるプ ロセス機器

新規性を有した溶射機器などのプロセス機器に関する学 術的報告はほとんどみられなかった。論文題目で内容を 見るに、HVOF ガンのノズル形状の粉末付着効率への影響 ${ }^{233)} 、 フ ゚ ラ ス ゙ マ$ 溶射装置 ${ }^{234)}$ 、水プラズマ溶射と HVOF 溶射 の重畳効果 ${ }^{235)}$ 、交差電極型プラズマ溶射ガン ${ }^{236)}$ 、Double

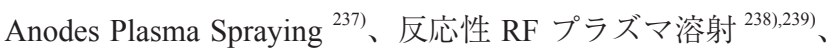
雲囲気制御法 ${ }^{240)}$ 、水中ショックコンパクション ${ }^{241)}$ 、真空アー 
ク処理 ${ }^{242), 243) 、 タ ゙ イ レ ク ト タ ゙ イ オ ー ト ゙ レ ー サ ゙ ー ~}{ }^{244)}$ で示され る 12 編であった。

3.6 分野 6 : 溶射現象の測定・診断手法、現象の観察・モデ ル化・シミュレーション

26 編を取り上げた。金属液滴の自由落下、基板衝突実験 を端緒として、これらの手法で溶射現象を観察し、溶射粒 子スプラットの形成状況を直接観察する動きは福本らが先 駆けて系統的に実施した。このことはこの分野ですでに世 界的に評価されている。論文数は 13 編。プラズマ溶射ス

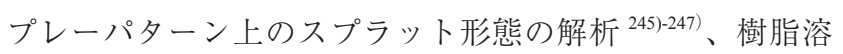
射粒子の扁平形態と密着強度の相関性 ${ }^{248)}$-250) 、さらに溶射

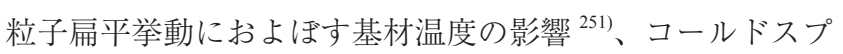
レー法による銅粒子堆積機構の解明 ${ }^{252)}$ の報告がある。安 藤らは二次電池容器の内面に $\mathrm{Cr}-\mathrm{Fe}$ 合金をプラズマ溶射被 覆する際の $\mathrm{Cr}-\mathrm{Fe}$ 溶射粒子の扁平挙動、基材への密着性に 及ぼす基材予熱温度の影響を報じた ${ }^{253)}$ 。このほか、高速ガ ス炎溶射法における固液共存面への固化粒子の付着挙動 ${ }^{254)}$ や、村上らは鉄、鉄、ニッケル、銅など単成分金属皮膜の 積層構造、その皮膜特性を論じている ${ }^{255)-257) 。 ~}$

一方、これらの実験的調査に対して、解析によるものは 溶射粒子扁平堆積現象の一次元解析などの理論的検討であ り、片野田 7 編、小川 3 編、黒田 1 編ら、特定グループが 実行した 12 編の報告がある。キーワードは数值シミュレー

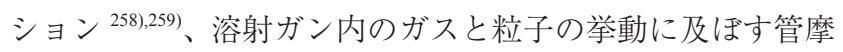
擦、冷却、ノズル形状の影響に関する一次元解析 ${ }^{260), 261), 266) 、 ~}$ 運動方程式の近似解に基づく粒子の加速原理考察 ${ }^{262) 、}$ 、粒子 衝突シミュレーション 264)、粒子堆積臨界速度考察 ${ }^{265)}$ 、超音 速自由噴流の半実験式を用いた高速フレーム溶射の粒子挙 動の理論解析 ${ }^{267)}$ 、分子動力学法 ${ }^{269)}$ 、エアロゾルデポジショ ンにおける解析 ${ }^{263), 268)}$ に代表される。また、皮膜割れ挙動 のシミュレーション ${ }^{270)}$ が1編提案されていた。

\section{7 分野 7 : 皮膜 / 改質層の作製にかかる前後処理}

溶射皮膜は基材に被覆してそのままの状態で直ちに実用 できる特性を有したプロセスのひとつであり、これが他の 表面改質プロセスに比べて優れている特徴でもある。しか し、材料形成が熱履歴、塑性変形をともなう非定常条件下 で進行するため、物質としての平衡状態にあるとは言いが たい。これは基材の表面を構成する材料層としての性質、 機能に不十分さをともなう。このため多くの研究者が溶射 層形成前後の何らかの処理を検討してきた。今回調査した 36 編の文献をみると、基材のブラスト粗面化加工 ${ }^{271)-280)} 10$ 編、レーザー加熱の併用 ${ }^{281-290)} 10$ 編、溶射皮膜の熱処理 ${ }^{291)-}$ 299) 9 編、真空アーククリーニング ${ }^{300)-303)} 4$ 編、皮膜の研摩 . 研削加工 ${ }^{304)-305)} 2$ 編、溶射皮膜に対する金属融体の浸透処 理 ${ }^{306)} 1$ 編が報告されていた。ブラスト粗面化加工では、基 材のピーニング効果、表面温度、研削材噴射角度、ブラス 卜加工量産化手法などを対象としている。真空アークク
リーニングは基本プロセスとして溶射の分野ではあまり採 用されていないが金属基材の粗面化を実行するものの一手

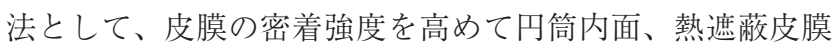
の施工の前処理法を提案している。溶射と独立したレー ザー熱源を溶射と同時、あるいは皮膜被覆後に表面加熱 · 再溶融手段として用いる報告が特定の研究者からあった。 レーザー溶射なるものは 25 年以上前から提案されているも のの、この 10 年でも実用化に寄与する提案はそしく、今 後皮膜積層形成の実用工法となる可能性は低いと考えられ る。

\section{8 分野 8 : 工業的応用事例}

溶射皮膜とその関連製品は耐摩耗・形状維持、腐食科学・ 防食工学: 水溶液・高温、溶融塩、溶融金属、エネルギー: 熱遮蔽・電池・発電用、絶縁・誘電など電磁気的機能、環 境浄化、肉盛再生などに対する有効な表面改質手段として 発展し、工業分野に取り入れられてきた。今回調査した範 囲では学術的見地から取り組んだ論文は 13 編であった。そ の内容は、 $\mathrm{Ti}$ 板深絞り加工用金型への被覆 ${ }^{307)}$ 、バリス夕素 子における $\mathrm{Al}$ 溶射被覆した電極 ${ }^{308)}$ 、廃棄物発電プラント

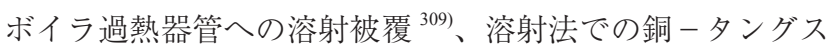

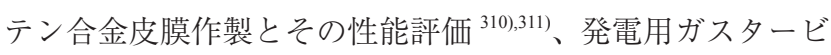
ン部材では動静翼部材被覆皮膜における熱時効 ${ }^{312}$ 、熱疲労 寿命 ${ }^{313)}$ 、皮膜内縦割れ導入の機能性 ${ }^{314)} 、 \mathrm{MoSi}_{2}$ 中間層設置 の提案 ${ }^{315)}$ 、タービン燃焼器に対する皮膜の損傷評価 ${ }^{316)}$ が 開示されていた。ナトリウム硫黄二次電池適用では、最長 10 年間実用した単電池容器の溶射皮膜の耐硫化腐食性と基 材密着特性の報告 ${ }^{317)}$ があった。そのほか、静電吸着能を 有するアルミナ溶射皮膜の開発経緯 ${ }^{318)}$ 、液晶パネル用無ア ルカリガラス板製造ライン冷却炉における薄厚ガラス搬送 ロール被覆皮膜の耐環境性に言及する報告 ${ }^{319)}$ があった。

\section{9 分野 9 : 総説 · 解説 $\cdot$ その他}

今回調査した各誌とも、ある頻度で特定の学術分野に焦 点を絞った特集号が企画された。内容を溶射分野に特定す る日本溶射協会誌、年一回の特集号を企画する高温学会誌 を初めとするほか、まてりあ、表面技術誌、日本ガスター ビン学会誌の 3 誌がほぼ 10 年間に一度と考えられるような 溶射に関する特集記事を掲載した。投稿は、原著論文では なく解説や総説記事である。調査した範囲では 48 編に達 した。広範な分野を対象としている。取り上げる内容分野. 頻度の大きいものから概観した。

総説は 4 編で、主として工業的利用における溶射技術動

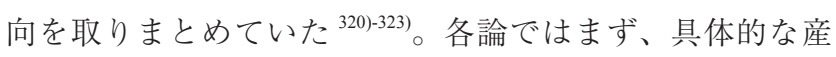
業適用事例が 19 編あった。その内訳を見るに、発電用ガス タービン高温部材に対する溶射加工・熱遮蔽コーティング に関するものは 7 編 ${ }^{335), 342)-345), 347), 349)}$ であった。ガスタービ ン動翼部材に対する MCrAlY 合金皮膜の熱機械的疲労と耐 用寿命、熱遮蔽層を構成する下地層の耐酸化機構。余寿命 
評価手法などに焦点が絞られている。ボイラプラントは 4 編で、熱交換器管部材の耐高温腐食抑制のエンジニアリン グ ${ }^{333)}$ 、廃棄物燃焼機構耐久性支援皮膜の提案 ${ }^{334), 336,348)}$ が

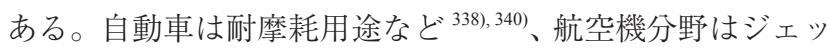

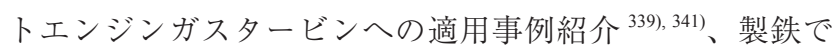
は鋼材連続鋳造鋳型への適用 ${ }^{337}$ 、鉄鋼構造物に対する犠牲 防食皮膜 ${ }^{346)}$ 、発電用ガスタービン部材への適用 ${ }^{350)}$ 、電力 貯蔵用二次電池部材への適用 ${ }^{351)}$ となっていた。20世紀終 端の 20 年間に発表されたものに比べ概して新規性は乏し いのが筆者の所感であった。応用分野の多岐性から、耐高 温腐食性を付与する溶射皮膜のレビューが 5 編認められた。 産業用ボイラプラントへの溶射適用が浸透した近年である ので、喜ばしいことである。表面改質の効果をエンジニア リング的に捉える価值ある行動といえよう。産業分野への 応用の実態を学術的に報告するものは以外と少ない。自動 車、鉄鋼産業、航空機、二次電池に対するものがあったが、 半導体・液晶、産業機械などの分野は取りまとめに困難さ をともなうことや、守秘上の情報取り扱い制約からそれら の応用内容はほとんど開示されていない。溶射とその関連 技術は、ものづくりに直結する要素生産技術であるという 考え方をすれば当然のことかもしれない。

溶射皮膜特性に 9 編が言及した。その内容を開示順に示 す。プラズマ溶射セラミック皮膜 ${ }^{324)}$ 、耐高温腐食皮膜 ${ }^{325)}$ 、 鉄基非晶質合金 ${ }^{326)}$ 、ガスタービン用超合金皮膜の疲労と寿 命推定 ${ }^{327)}$ 、ガスタービン用合金皮膜の損傷解析 ${ }^{328)}$ 、生体 適用表面改質 ${ }^{329)}$ 、耐酸化皮膜と $\mathrm{Ni}$ 基合金の拡散 / 金属組 織 ${ }^{330)}$ 、耐摩耗表面改質プロセスとその皮膜 ${ }^{331)}$ 、炭化物サー メット皮膜の耐水溶液腐食性 ${ }^{332}$ である。

評価法の解説は遮熱コーティングの寿命推定 ${ }^{352) 、 コ ー ~}$ ティングの損傷機構と評価技術 ${ }^{353)}$ 、耐熱皮膜の性能評価試 験法の標準化 ${ }^{354)}$ と、いずれもガスタービン部材用熱遮蔽 皮膜に集中した。溶射機器・プロセスは 7 編とりあげられ た ${ }^{355)-361)}$ 。しかし、20 世紀終端の 1980 年以降のような実用 化したとの点で画期的なものは認められない。溶射プロセ

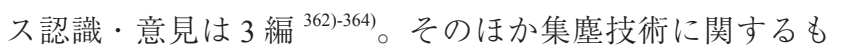
の ${ }^{365)}$ 、中小溶射業界を聞き取り調査で統計的に捉えようと の試み ${ }^{366), 367)}$ があった。

\subsection{0 その他}

本分野での学位取得を目的として、系統的に技術を取り まとめようとする動きが少なからず認められた。溶射とそ の関連分野を学術的に体系化するのに有効な活動として今 後も展開されることが望まれる。

\section{4. おわりに}

国内刊行学術誌に掲載された原著論文ならびに解説・総 説を対象に、溶射とその関連分野の学術・技術の動向を調 べた。溶射とその関連生産活動はすでに開示された資料 ${ }^{368)}$
によると着実に活発になっていることを知ることができる が、これらの工業技術を基礎的に支援する学術活動が有効 に機能しているかどうか、一部を除き議論の余地のあると ころである。発電用ガスタービンプラントやボイラプラン 卜の高温域部材には溶射皮膜が定常的に使われており、そ の活用に指針を与えるエンジニアリング的内容を有した原 著論文の投稿増加がさらに期待される。本稿では個々の論 文が提起する学術的情報には細かく触れてはいないが、こ の 10 年間の材料系学術論文が溶射とその関連技術にどのよ うにかかわりそれらを表現してきたのか、その一面を理解 するための資料として利用いただけるならそれは幸いであ る。

文末に、米国 ASM インターナショナル 溶射部会が中心 となって発行している Journal of Thermal Spray Technology 誌の影響について少し述べる。筆者の調査によれば、2000 年からの 10 年間で、査読を経た論文 (Reviewed paper) 674 編が刊行されている。わが国からのものも少なくはないが、 溶射とその関連分野における全世界からの投稿を受け入れ ており、数のうえでは今回調査した国内論文を大幅に超え ている。研究の論点も多岐でわが国にはない視野も多く、 近い将来、機会があればそれらの実態を開示したい。なお、 本文献調査には当研究所 高橋美佐所員の協力を得た。ここ に記して謝意を表します。

\section{引用文献}

1）沖 幸男、上野和夫、袖岡 賢、鈴木正人、小野幸徳：反応性 プラズマ溶射によるフェライト系ステンレス鋼の窒化処理、 溶射、37-4 (2000)、175-182.

2) 福本昌弘、西尾庄司: 高周波熱プラズマ溶射法による Ti(C、N)/ $\mathrm{Ti}$ 複合皮膜の作製、溶射、38-4 (2001), 200-205.

3) Masahiro Okumiya, Yoshiki Tsunekawa, Kanehiro Fukaya and Naotake Mohri : Formation of TiC/Ti2AlC Composite Layer and Improvement on Surface Roughness, Mater. Trans., 42 (2001)-8、 1717-1722.

4) 星山康洋、三宅秀和、村上健児、中嶋英雄：反応性溶射によ る窒化物粒子分散チタンアルミナイド基複合皮膜の作製、日 本金属学会誌、66-7 (2002), 784-791.

5) Motohiro Yamada, Tatsuya Inamoto, Masahiro Fukumoto and Toshiaki Yasui : Fabrication of Silicon Nitride Thick Coatings by Reactive RF Plasma Spraying, Mater. Trans., 45 (2004)-12, 33043308.

6) 村上健児、石川寬、他：ミリング助剤を炭素供給源とする $\mathrm{Ti} / \mathrm{A} 1$ 複合粉末を用いたチタンアルミナイド - 炭化物複合溶射 皮膜の作製、高温学会誌、31 (2005)、338-346.

7) 西田 稔、荒木孝雄：レーザー溶射による TiNi 形状記憶合金 の作製、高温学会誌、32 (2006)、230-235.

8) 福本昌宏: 溶射法による光触媒チタニア皮膜創製の可能性、 高温学会誌、26 (2000)、240-247.

9) 松坂壮太、大森明、他： $\mathrm{TiO}_{2}-\mathrm{Al}$ 複合粉末を用いた光機能溶 射皮膜の作製とその性能評価、高温学会誌、27 (2001)、274- 
279

10) Young-gyo JUNG, SUZUKI Terumi and FUKUMOTO Masahiro : Inventigation of Microstructure of Thermal Sprayed $\mathrm{TiO}_{2}$ Coating Photocatalyst and Improvement of its Performance by Adsorbent Addtion, 溶接学会論文集、20-1 (2002), 152-157.

11) 福本昌宏、鄭 瀅教、鈴木照実、熱田直行、他：光触媒溶射 皮膜の作製およびNOx 除去特性に及ぼす各種添加物の影響、 溶接学会論文集、22-1 (2004)、47-52.

12) 安岡淳一、大森明、他：アナターゼ型 $\mathrm{TiO}_{2}$ ナノ粒子造粒粉末 の適用による光触媒溶射皮膜の創製、高温学会誌、30 (2004)、 316-321.

13）中村信広：溶射加工法を用いた光触媒皮膜の製作プロセスと その特性について、日本機械学會論文集 C 編 72(715)、2006、 47-952.

14) 二俣正美、伊藤英信、他：撥水機能と光触媒機能を有する粒 子分散型溶射皮膜の開発、高温学会誌、32 (2006)、343-348.

15) 中山勝、奥山哲也：線爆溶射法によるアモルファス合金皮 膜作製用合金線材の作製とその皮膜アモルファス化、溶射、 42-4 (2005)、151-155.

16) Ai Ping Wang, Tao Zhang and Jian Qiang Wang: Formation and Properties of Ni-Based Amorphous Metallic Coating Produced by HVAF Thermal Spraying, Mater. Trans., 46 (2005)-5, 1010-1015.

17) 長尾直子、小牧正博、倉橋隆郎、針原保典：溶射法による アモルファス合金皮膜の積層技術の開発、日本金属学会誌、 71-9 (2007)、742-746

18）五十嵐貴教、石川貴士、杉山雅治、大原正樹、福本昌宏、木 村久道、井上明久：高速フレーム溶射法 (HVOF) による Fe 基金属ガラス皮膜の創製、溶射、45-1 (2008)、1-4.

19) Jin Kawakita, Norio Maruyama, Seiji Kuroda, Sachiko Hiromoto and Akiko Yamamoto : Fabrication and Mechanical Properties of Composite Structure by Warm Spraying of Zr-Base Metallic Glass, Mater. Trans., 49 (2008)-2, 317-323.

20) 福本昌宏、鄭 教、尾関啓治、山田好伸：ナノ組織 WC-Co MA 粉末の HVOF 溶射および皮膜特性評価、溶接学会論文集、 21-4 (2003)、609-613.

21) Sheng-Qiang Fan, Chang-Jiu Li, Cheng-Xin Li, Guang-Jian Liu, Guan-Jun Yang and Ling-Zi Zhang : Preliminary Study of Performance of Dye-Sensitized Solar Cell of Nano-TiO2 Coating Deposited by Vacuum Cold Spraying, Mater. Trans., 47 (2006)-7, 1703-1709.

22) Kai Tao, Xianglin Zhou, Hua Cui and Jishan Zhang: Preparation and Properties of a Nanostructured NiCrC Alloy Coating for Boiler Tubes Protection, Mater. Trans., 49 (2008)-9, 2159-2162.

23) 菱田元樹、藤田 雅、榊 和彦：コールドスプレーによるナノ 準結晶分散アルミニウム合金皮膜の作製、日本金属学会誌、 73-6 (2009)、421-428.

24) 川瀬良一、森山智代、他：セラミックスとプラスティックの 複合 (セラプラス) 溶射皮膜に関する研究、高温学会誌、26 (2000)、240-247.

25）川瀬良一、水間 歩、他：セラミックスとプラスティックの複 合 (セラプラス ) 溶射皮膜に関する研究 - 流動床造粒法によ る複合粉末と溶射皮膜性能一、高温学会誌、28 (2002)、281-
288.

26) 渡邊宏、田中康徳、川瀬良一：マイクロカプセル $\mathrm{TiO}_{2} /$ プラ スティック複合皮膜の作製、溶射、42-3(2005)、117-122.

27) Manabu Matsubara, Toshihiko Iwasaki and Shuji Hanada：傾斜機 能させた $\mathrm{Nb}-\mathrm{Al} / \mathrm{Al}_{2} \mathrm{O}_{3}$ 皮膜のプラズマ溶射による作製、日本 金属学会誌、64-8 (2000), 677-683.

28) Fei CHEN, Qiang SHEN, Julie M. SCHOENUNG and Lianmeng ZHANG : Preparation of pore gradient silicon nitride ceramics by a high-velocity oxy-fuel spraying technique, J. Ceram. Soc. Jpn, 117 (2009)-1364, 445-448.

29) 福本昌弘、佐々木宏和、安井利明：プラズマCVD 法による ダイヤモンド合成の広面積化、溶射、40-2 (2003)、57-62.

30) 安藤康高、戸部省吾、田原弘一、吉川孝雄：Mo 大気溶射を 施したステンレス基材上への然焼炎法によるダイヤモンド合 成、溶射、42-1 (2005)、17-21.

31) 田村英樹：高速・高密度セラミックジェットによる溶射複合 コーティングの探索、高温学会誌、26 (2000)、233-239.

32) 水迫文樹、田村英樹、他：電熱爆発粉体溶射法による Zr-O-B 系複合物 $-\mathrm{Ni}-20 \% \mathrm{Cr}$ 傾斜構造皮膜の形成、高温学会誌、 28 (2002)、274-280.

33) 鴨下泰久、二俣正美：フッ素化カーボンと溶射皮膜の複化に よる着水防止皮膜の開発、一塗布法の場合について - 、高温 学会誌、26 (2000)、219-224.

34) 片平和俊、池 正根、鈴木秀人、安藤秀泰：WCプラズマ溶 射 FDI の「P-S-N 球儀」に果たす表面メゾ構造の役割に関す る線形切欠力学的検討、日本機械学會論文集 A 編 66(642)、 2000、298-303.

35) 山田 毅、都筑隆之、佐藤広明：溶射プリフォームを利用した $\mathrm{SiC}$ 繊維強化 $\mathrm{Ti}$ 基複合材料の作製、日本金属学会誌、65-10 (2001)、946-954.

36) 河野亮、山田毅、藤原力、福島明、廣田雅、河内幸雄 : ワインディング/溶射法による $\mathrm{SiC}$ 長繊維/ $\mathrm{Ti}$ 基複合材料リ ングの製造プロセス、日本金属学会誌、65-12 (2001)、11041107.

37) 伊藤義康、須山章子、新藤尊彦、安藤秀泰：セラミックス表 面へのアルミニウムのショットコーティング、日本金属学会 誌、65-5 (2001)、443-448.

38) 濱中一平、恒川好樹、奥宮正洋、福本昌弘：インプロセス反 応を伴う $\mathrm{SiO} 2 / \mathrm{Al}-\mathrm{Mg}$ 合金系造粒粉末の HVOF 溶射、溶射、 39-1 (2002)、1-6.

39）金沢朋実、大森明：プラズマ溶射法による溶射粒子の打ち込 みと膜形成による廃 PET の高機能表面改質、高温学会誌、28 (2002)、295-301.

40) 二俣正美、中西喜美雄、岩井聖晴、鴨下泰久、他：溶射法に よる撥水性および抗菌性環境対応皮膜の開発、溶接学会論文 集、21-3 (2003)、460-465.

41) 清水保雄、榊 和彦、他：カーボンナノファイバー/ポリエ チレン樹脂複合溶射粉末の作製と溶射への適用、溶射、41-2 (2004)、52-57.

42) 奥野晃康、原田良夫、安藤孝志：電力貯蔵 NAS 電池用 $\mathrm{Al}$ 容 器への内面プラズマ溶射の開発、溶射、41-1 (2004)、1-6.

43) 安藤孝志、原田良夫：NAS 電池用 $\mathrm{Al}$ 格納容器内面への高ク 
ロム - 鉄合金溶射皮膜の開発、溶射、42-2 (2005)、68-74.

44) 植松 進、石崎祥希、他 : 反応性プラズマ溶射法による $\mathrm{SrTiO}_{3}$ 皮膜創製とその特性評価、高温学会誌、30 (2004)、330-335.

45) Hideki YOSHIOKA : "Fabrication and ionic conductivity of apatite-type $\mathrm{Mg}$ doped lanthanum silicate films by DC plasma spraying ",J. Ceram. Soc. Jpn, 117 (2009)-1361, 99-101.

46) Kun Yu, Chao Li, Richu Wang and Jun Yang : Production and Properties of a Spray Formed 70\%Si-Al Alloy for Electronic Packaging Applications,Mater. Trans., 49 (2008)-3, 685-687.

47) Masahiro Fukumoto, Min Nie and Toshiaki Yasui : Preparation and Evaluation of Ordinary Attritor Milled Ti-Al Powders and Corresponding Thermal Sprayed Coatings, Mater. Trans., 47 (2006)-7, 1717-1722.

48) 中村信広、生田稔郎：溶射・溶融法による湿式光センサーの 開発に関する基礎的研究、日本機械学會論文集 C 編 66(644)、 2000、1374-1379.

49) 上野和夫、袖岡 賢、鈴木正人、他：雲囲気制御プラズマ溶射 による $\mathrm{FeSi}_{2}$ 熱電素子の溶射形成、溶射、37-2 (2000)、53-60.

50) JUNG Young-gyo, FUKUMOTO Masahiro and OZEKI Keiji : Characteristic of Ni Powder by Mechanical Alloying and Application to HVOF Thermal Spraying, 溶接学会論文集、20-3 (2002), 408-414.

51) 福本昌宏、田中季夫、笹岡 稔、山田基宏、安井利明：ダイヤ モンド研磨用 TiAl 溶射皮膜の創製およびその特性評価、溶 接学会論文集、24-4 (2006)、357-361.

52) 岩澤順一、西水亮市、常田昌広、他：エアロゾルデポジショ ン法による緻密イットリア膜の室温形成、日本セラミックス 協会学術論文誌、114-3 (2006)、272-275.

53) 中村信広、生田稔郎： $\mathrm{Ti}$ 窒化物基材に製作した $\mathrm{TiO}_{2}$ 溶射皮 膜の電極特性、溶射、37-1 (2000)、6-10.

54) Keiji SONOYA, Chang-Jiu LI and Fu-Hai LI : Relationships between Microstructure, Mechanical Properties of Plasma-sprayed Ni-50Cr Coatings and Spray Parameters, 溶接学会論文集、19-1 (2001), 27-36.

55) Byoung Hee Kim and Dong Soo Suhr : Characteristics of HVOFSprayed WC-Co Cermet Coatings Affected by WC Particle Size and Fuel/Oxygen Ratio,Mater. Trans., 42 (2001)-5, 833-837.

56) Byoung Hee Kim and Dong Soo Suhr : The Effect of Oxygen Flow Rate in HVOF Spraying on Oxidation Behavior of $\mathrm{Cr} 3 \mathrm{C} 2$ (7 mass\%NiCr) Coatings, Mater. Trans., 42 (2001)-4, 707-711.

57) 佐竹忠昭、菅野幹男、他：プラズマ溶射アルミナ被覆処理ス テンレス鋼の腐食疲労強度に及ぼすグリットブラスト処理効 果、高温学会誌、28 (2002), 265-273.

58) 峪田宣明、飛田守孝、田尻登志郎、他：アーク溶射 Ti 複合 皮膜に及ぼすアトマイズガスと熱処理の影響、溶射、40-2 (2003),52-56.

59) 石川量大、戸部省吾 : 溶線式フレーム溶射法によるアルミニ ウム溶射皮膜の密着性に及ぼすブラスト角度と溶射角度の影 響、溶射、40-3 (2003),107-112.

60) 屋良秀夫、Budi Prawara、他： $\mathrm{NiAl}$ 及び $\mathrm{Al}_{2} \mathrm{O}_{3}$ 溶射粉末によ る積層並びに混合皮膜の性状に及ぼす溶射条件の影響、高温 学会誌、29 (2003), 115-121.
61) 高橋 智、吉葉正行、原田良夫：プラズマ溶射法による遮熱コー ティングシステムの高温酸化特性に及ぼすコーティングプロ セスの影響、日本金属学会誌、68-7 (2004), 438-446.

62) 田原弘一、安藤康高：窒素・水素混合ガス及びアンモニアを 用いた超音速プラズマジェットのプラズマ状態とチタン基材 の窒化特性、溶射、42-1(2005), 6-11.

63) 桑嶋孝幸、堀江 皓、斉藤裕之、大森明：鋳鉄溶射皮膜組織 に及ぼす溶射条件の影響、溶射、42-2 (2005), 75-79.

64）上野和夫、榊 和彦、新海修平、清水保雄：コールドスプレー 成形された金属銅の特性に及ぼす成形ガス圧力の影響、溶射、 42-3 (2005),167-171.

65) Jin Kawakita, Seiji Kuroda, Sebastian Krebs and Hiroshi Katanoda : In-Situ Densification of Ti Coatings by the Warm Spray (Two-Stage HVOF) Process, Mater. Trans., 47 (2006)-7, 1631-1637.

66) Wei-Ze Wang, Chang-Jiu Li and Yu-Yue Wang : Effect of Spray Distance on the Mechanical Properties of Plasma Sprayed Ni- 45Cr Coatings, Mater. Trans., 47 (2006)-7, 1643-1648.

67) Yasunari Ishikawa, Jin Kawakita and Seiji Kuroda : Effect of Spray Condition and Heat Treatment on the Structure and Adhesive Wear Properties of WC Cermet Coatings, Mater. Trans., 46 (2005)-7, 1671-1676.

68) 木戸光夫、平野哲也、徳田太郎、他：WC-Co 系サーメット 溶射材の溶射圧力および皮膜成分による腐食疲労強度の向 上、材料、 55 (2006)-11, 1004-1010.

69) 荒井正行：プラズマ溶射条件と遮熱コーティングの機械的特 性の関係、日本機械学會論文集 A 編 75(754), 2009, 697-702.

70) 寺谷武馬、水津竜夫、谷和美、原田良夫：クロメート処理に よる MCrAlY 溶射皮膜へのアルミナ保護膜の形成、高温学会 誌、29 (2003), 247-252.

71) 高橋 智、吉葉正行、木村浩史、原田良夫：プラズマ溶射 $\mathrm{TBC}$ システムのクリープならびに疲労強度特性に及ぼすボン ドコートプロセスの影響、日本金属学会誌、72-5 (2008), 317322.

72) 山崎泰広、杵淵稔夫、深沼博隆、大野直行 : 大気プラズマ溶 射遮熱コーティングの密着強度に及ぼす界面粗さとボンド コート施工方法の影響、材料、57 (2008)-6, 596-602.

73) 佐竹忠昭、武田武信 : アルミナ被覆処理ステンレス鋼の生理 食塩水中における疲労特性に及ぼす Ti アンダーコートの影 響、高温学会誌、35 (2009), 215-222.

74) Magdi F. Morks, Yoshiki Tsunekawa, Masahiro Okumiya and Madiha A. Shoeib : Microstructure of Plasma-Sprayed Cast Iron Splats with Different Particle Sizes, Mater. Trans., 44 (2003)-4, 743-748.

75) 大澤悟、五日市剛：造粒焼結した $\mathrm{Cr}_{3} \mathrm{C}_{2}$ 系サーメット粉末の 粒度㧍よび顆粒強度が HVOF 溶射特性に及ぼす影響、溶射、 41-2 (2004), 58-63.

76）桑嶋孝幸、園田哲也、安岡惊一、斉藤貴、鈴木一考、他: コー ルドスプレー法によるサーメット材料の成膜と粉体圧縮粉砕 強度が成膜性に及ぼす影響、溶射、46-3 (2009),80-85.

77) 松原洋一、宝慧圭子：プロセスロールにおける WC-Co 溶射 皮膜の破壊に及ぼす基材硬さの影響、高温学会誌 29 (2003), 241-246. 
78) Motohiro Yamada, Hajime Nakamura, Toshiaki Yasui, Masahiro Fukumoto and Koyata Takahashi : Influence of Substrate Materials upon Fabrication of Aluminum Nitride Coatings by Reactive RF Plasma Spraying,Mater. Trans., 47 (2006)-7, 1671-1676.

79) 張 東坤、加藤昌彦、中佐啓治郎、丁象賢：高速フレーム溶射 した WC-Co 皮膜の剥離強度に及ぼす基材硬さの影響、材料、 50 (2001)-11, 1262-1268.

80) FUKUSHIMA Takeshi and KURODA Seiji : Oxidation of HVOF Sprayed 316L Stainless Steel Coatings and Its Control by A Gas Shroud, 溶接学会論文集、20-3 (2002), 439-444.

81) Mitsuhiro Shibata, Seiji Kuroda, Hideyuki Murakami, Machiko Ode, Makoto Watanabe and Yukihiro Sakamoto : Comparison of Microstructure and Oxidation Behavior of CoNiCrAlY Bond Coatings Prepared by Different Thermal Spray Processes, Mater. Trans., 47 (2006)-7, 1638-1642.

82）鈴木賢治、田中啓介、秋庭義明、他：高エネルギー放射光に よる遮熱コーティングのボンドコートの高温その場測定、材 料、 52 (2003)-7, 756-763.

83) 大木基史、石橋達弥、鈴木隆之、高橋雅士：押し达み試験 方方式を利用した遮蔽コーティングのヤング率測定、溶射、 41-4 (2004), 152-159.

84）荒井正行：界面酸化過程を考慮した界面結合モデルに基づく 遮熱コーティングの剥離強度評価法の提案、材料、53 (2004)-4, 459-464.

85）鈴木賢治、久保貴博、田中啓介、秋庭義明、他：放射光による 遮熱コーティングの酸化損傷と剥離応力の解析、材料、53 (2004)-7, 734-739.

86) Motofumi Ohki, Tatsuya Ishibashi and Jun Kinoshita: Influence of Load Dependency and Coating Anisotropy on Calculated Young's Modulus of TBCs by Indentation Test, Mater. Trans., 47 (2006)-4, 1170-1177.

87) Hiroyuki Waki and Akira Kobayashi : Development of Lateral Compression Method of Circular Tube Thin Coating for Mechanical Properties of Plasma Sprayed CoNiCrAlY, Mater. Trans., 47 (2006)7, 1626-1630.

88) 高橋 智、吉葉正行、原田良夫：プラズマ溶射遮熱コーティン グシステムの室温ならびに高温における機械的損傷のその場 観察、材料、55 (2006)-12, 1125-1132.

89) 岡田満利、久松暢、北村隆行: 遮熱コーティングのボンドコー 卜組織変化に着目した温度推定手法およびアルミニウム含有 量予側手法の検討、材料、56 (2007)-8, 757-763.

90) 加藤昌彦、中佐啓治郎、趙 保華、他：クリープ変形を受ける 8 mass $\% \mathrm{Y}_{2} \mathrm{O}_{3} \cdot \mathrm{ZrO}_{2} / \mathrm{CoNiCrAlY}$ 熱遮蔽コーティングの剥離寿 命評価、材料、57 (2008)-12, 1198-1204.

91) 山崎泰広、吉田敏彦、深沼博隆、大野直行：遮熱コーティン グの熱サイクル損傷と残存密着強度、材料、58 (2009)-2, 168174.

92）荒井正行: 押し达み試験法に基づくセラミック遮熱コーティ ングの界面破壊勒性評価法、材料、58 (2009)-11, 917-923.

93) 伊藤義康、須山章子、布施俊明：変形測定によるコーティン
グ部材の残留応力評価、溶射、42-4 (2005), 156-160.

94) 伊藤義康、須山章子、布施俊明：変形測定によるブラスト加 工部材の残留応力評価、溶射、43-1 (2006), 1-6.

95) 伊藤義康、須山章子：固有ひずみ法によるプラズマ溶射部材 の残留応力評価、日本機械学會論文集 A 編 73(726),2007,189194.

96) 村田一夫：X線による残留応力測定上の諸問題 - 各種測定 事例とアルミナ溶射面の残留応力－、溶射、44-4 (2007), 147153.

97) 脇 裕之、廣田裕也、小林 明：円管横圧縮による溶射皮膜の 曲げ強度の簡便・高効率評価法の考案、日本機械学會論文集 A 編 74(746), 2008, .1342-1350.

98) 脇 裕之、西井雅宏、小倉敬二、西川出：皮膜ひずみ計測に よるアルミナ溶射 SUS304 鋼の高温疲労過程の観察、日本機 械学會論文集 A 編 66 (648), 2000, 1520-1525.

99) MURAMATSU Yoshiki and KURODA Seiji: Examination of the Debonding Behavior of Thermal Sprayed Coatings by Local Heating on Substrate Plate -Application of the Laser Speckle Method to Strain Measurement in the Welding Precess (Report 4)-, 溶接学会論文集、20-2 (2002), 287-294.

100）新原美子、木戸光夫、徳田太郎、大谷幸三、他：溶射材の皮 膜剥離の AE 法による検出、溶射、44-2 (2007), 37-42.

101) Yoshiko Shinhara, Rongguang Wang, Tarou Tokuda, Mitsuo Kido, Yoshio Harada and Shinji Wada: "Surface Strain Measurement of Thermally Sprayed Ceramics Coatings under Static and Cyclic Loadings and Its Application to Detection of Delamination", Mater. Trans., 48 (2007)-4, 769-774.

102）大谷幸三、新原美子、福島千晴、木戸光夫、馬場 充：レーザ レンジファインダによる溶射皮膜のはく離状態と 3 次元位置 の同時検出、日本機械学會論文集 C 編 75(752), 2009, 796-804.

103) 杉山憲一、服部修次：サーメット系溶射皮膜のスラリー摩耗 深さ予測、日本機械学會論文集 A 編 73(733), 2007, 1058-1064.

104) 渡邊誠：溶射皮膜の密着性評価手法に打ける課題、溶射、 46-4 (2009), 121-124.

105) 荒井正行、岩田宇一、佐久間俊雄 : 遮熱コーティングと基 材の剥離発生強度に及ぼす熱時効の影響、材料、49 (2000)-8, 912-918.

106) 大木基史、武藤睦治、高橋雅士、石橋達弥: 傾斜組成遮熱コ一 ティングの熱サイクル損傷機構、溶射、38-4 (2001),190-199.

107) 于志明、田海啓司、成田敏夫：遮熱コーティング皮膜の $1173 \mathrm{~K}$; 硫黄分圧 $10^{-0.26} \mathrm{~Pa}$ における硫化腐食挙動、材料と 環境、50-8 (2001), 379-379.

108) 鳴海雅稔、于 志明、田海啓司、成田敏夫：プラズマ溶射 CoNiCrAlY/YSZ 皮膜の 1173 と $1273 \mathrm{~K}$ における大気中酸化挙 動、材料と環境、50-10 (2001), 466-471.

109) 寺谷武馬、谷和美、原田良夫： $\mathrm{Ni}$ 基合金上に形成した MCrAlY 溶射皮膜の拡散挙動、高温学会誌、27 (2001), 264268.

110) 加藤俊樹、小川和洋、庄司哲雄：耐はくり性に優れた熱遮蔽 コーティングの開発、溶射、39-2 (2002),52-57.

111）脇 裕之、小倉敬二、西川出：単軸圧縮負荷下におけるプラ 
ズマ溶射遮熱皮膜の応力 - ひずみ応答、日本機械学會論文集 A 編 68 (673), 2002, 1375-1381.

112）脇裕之、小倉敬二、西川出、長沼博貴 : セラミック遮熱コー ティングを施したSUS304 の高温疲労破壊強度に及ぼす剥離 損傷の影響、材料、52 (2003)-6, 639-645.

113) Satoru Takahashi, Masayuki Yoshiba and Yoshio Harada: "NanoCharacterization of Ceramic Top-Coat/Metallic Bond-Coat Interface for Thermal Barrier Coating Systems by Plasma Spraying", Mater. Trans., 44 (2003)-6, 1181-1189.

114）小野木伯薰、主森哲雄、他：熱遮へいコーティングの界面 剥離挙動に及ぼす熱時効処理の影響、材料、52 (2003)-7, 807814.

115) Noriyuki Mifune and Yoshio Harada: Mechanism of Vertical Microcracking in $\mathrm{CaO} \cdot \mathrm{SiO} 2-\mathrm{CaO} \cdot \mathrm{ZrO} 2$ Sprayed Thermal Barrier Top Coating, Mater. Trans., 45 (2004)-5, 1788-1793.

116）川村昌志、尾角英毅、鈴木賢治、他: セラミック遮熱コーティ ングの内部応力に対する界面粗さの影響、材料、53 (2004)-9, 1019-1023

117) 高橋 智、吉葉正行、原田良夫："プラズマ溶射法による遮熱 コーティングシステムのセラミックトップコート／金属ボン ドコート界面のナノキャラクタリゼーション"、日本金属学 会誌、68-6 (2004)、372-380.

118）寺谷武馬、山野英明、三船法行、谷和美、原田良夫、岡崎正和: $\operatorname{MCrAlY}(\mathrm{M}: \mathrm{Ni} 、 \mathrm{Co})$ ボンドコート上の未溶融粒子の酸化現象 とトップコートのカ学的挙動に対する影響、日本金属学会誌、 68-12 (2004), 1060-1067.

119) 新見彰夫、長谷川 誠、香川 豊、川村昌志、末光 毅 : 大気プ ラズマ溶射法を用いた遮熱コーティングの高温熱曝露による 微細組織変化、日本金属学会誌、69-1 (2005), 67-72.

120) 松岡小百合、吉葉正行、高橋 智、角田亘、原田良夫、遮熱コー ティングシステムのクリープならびに疲労損傷に及ぼす高温 腐食環境効果、材料と環境、54-5 (2005), 238-244.

121）園家啓嗣、李長久、王衛澤：プラズマ溶射 YSZ の破壊勒性、 溶接学会論文集、24-1 (2006), 65-69.

122) 吉岡隆幸、有川秀行、岡田満利、久松暢、児島慶享: 遮熱コー ティングの酸化挙動に及ぼすボンドコート表面処理及びボ ンドコート中のイットリウムの影響、日本金属学会誌、70-1 (2006), 7-13.

123) Hongbo Guo, Hideyuki Murakami and Seiji Kuroda: Thermal Cycling Behavior of Plasma Sprayed Segmented Thermal Barrier Coatings, Mater. Trans., 47 (2006)-2, 306-309.

124) Takashi Sakai, Mitsuhiro Shibata, Hideyuki Murakami and Seiji Kuroda: Microstructural Investigation of CoNiCrAlY Coated NiBased Single Crystal Superalloy Prepared by LPPS, Mater. Trans., 47 (2006)-7, 1665-1670.

125）山崎泰広、杵淵稔夫、深沼博隆、大野直行 : 大気プラズマ溶 射遮熱コーティングの機械的特性に及ぼす溶射条件と高温曝 露の影響、溶射、44-3 (2007), 88-95.

126) Zhaoxiang Chen, Fuhe Yuan, Zhongguang Wang and Shijie Zhu: The Oxide Scale Formation and Evolution on Detonation Gun Sprayed NiCrAlY Coatings during Isothermal Oxidation, Mater. Trans., 48 (2007)-10, 2695-2702.
127) 岡崎正和：YSZ 遮熱コーティングの微構造と弾性係数、材料、 57 (2008)-11, 1121-1131

128）加藤昌彦、中佐啓治郎、趙 保華、他：クリープ変形を受ける $8 \mathrm{mass} \% \mathrm{Y} 2 \mathrm{O} 3 \cdot \mathrm{ZrO} 2 / \mathrm{CoNiCrAlY}$ 熱遮蔽コーティングの剥離 寿命評価、材料、 57 (2008)-12, 1198-1204.

129）田中誠、香川 豊：プラズマ溶射 TBC のランプリングした TGO 層中の局所応力分布、日本ガスタービン学会誌、37-2 (2009), 93-96.

130）岡田満利、久松暢、藤岡照隆、北村隆行：ガスタービンコー ティングの組織変化を用いた温度推定手法ーコーティング施 工方法が組織変化および推定温度に及ぼす影響一、材料、58 (2009)-4, 323-330

131）吉竹茂、飯尾哲史、船尾淳喜、有川秀行、他：熱疲労下に おける遮熱コーティングの剥離挙動、材料、58 (2009)-9, 759766.

132）竹田 睦、岡部卓治、木戸光夫、原田良夫：WC 系溶射皮膜 表面の $\mathrm{Na}_{2} \mathrm{SO}_{4}$ 水溶液下での腐食挙動、溶射、39-2 (2001), 5864.

133）竹田 睦、森弘尚希、木戸光夫、原田良夫：WC 系溶射皮膜 表面の $\mathrm{Na}_{2} \mathrm{SO}_{4}$ 水溶液に掞ける腐食挙動の経時的変化、溶射、 39-1 (2002), 7-12.

134）竹田 睦、森弘尚希、木戸光夫、原田良夫：WC 系溶射皮膜表 面の $\mathrm{Na}_{2} \mathrm{SO}_{4}$ 水溶液における腐食挙動の $\mathrm{pH}$ による変化、溶射、 39-3 (2002), 103-107.

135）森弘尚希、竹田 睦、原田良夫、木戸光夫： $\mathrm{Na}_{2} \mathrm{SO}_{4}$ 水溶液で WC 系溶射材表面に生じたさびの解析、溶射、39-4 (2002), 150-153.

136) 高谷泰之：溶射皮膜の耐食性、高温学会誌、28 (2002), 238246.

137) Mutsumi Takeda, Naoki Morihiro, Ryuichiro Ebara, Yoshio Harada, Rongguang Wang and Mitsuo Kido: Corrosion Behavior of Thermally Sprayed WC Coating in $\mathrm{Na}_{2} \mathrm{SO}_{4}$ Aqueous Solution, Mater. Trans., 43 (2002)-11, 2860-2865.

138) Seiji Kuroda, Takeshi Fukushima, Masaki Sasaki and Toshiaki Kodama: Microstructure and Corrosion Resistance of HVOF Sprayed 316L Stainless Steel and Hastelloy C Coatings, Mater. Trans., 43 (2002)-12, 3177-3183.

139) Jin Kawakita, Seiji Kuroda, Takeshi Fukushima and Toshiaki Kodama: Corrosion Resistance of HastelloyC Coatings Formed by an Improved HVOF Thermal Spraying Process, Mater. Trans., 44 (2003)-2, 253-258

140) Seiji Kuroda, Jin Kawakita, Takeshi Fukushima and Shogo Tobe: Importance of the Adhesion of HVOF Sprayed Coatings for Aqueous Corrosion Resistance, Mater. Trans., 44 (2003)-3, 381388.

141）森弘尚希、丁 亮、原田良夫、木戸光夫、他：WC-Co 系溶射 皮膜表面に水溶液下で生成するさびに含まれる $\mathrm{FeWO}_{4}$ の解 析、溶射、40-4 (2003), 154-158.

142) Fumitaka Otsubo and Katsuhiko Kishitake: Corrosion Resistance of Fe- $16 \% \mathrm{Cr}-30 \% \mathrm{Mo}-(\mathrm{C}, \mathrm{B}, \mathrm{P})$ Amorphous Coatings Sprayed by HVOF and APS Processes, Mater. Trans., 46 (2005)-1, 80-83.

143）佐竹優、新原美子、木戸光夫、徳田太郎、他: WC 系サーメッ 
卜被覆材の腐食疲労強度に及ぼす不働態挙動の影響、溶射、 45-2 (2008), 45-51.

144) 伊藤義康、安藤秀康、須山彰子：アルミニウム溶射皮膜の残 留応力特性、材料、49 (2000)-1, 56-60.

145) 伊藤義康、安藤秀康、新藤尊彦：溶射皮膜の破壊強度に及ほ す残留応力の影響、材料、49 (2000)-3, 310-315.

146) 金裕哲：溶射皮膜により残留応力がなぜ生じるの?、高温学 会誌、27 (2001), 244-249.

147）脇裕之、小倉敬二、西川出、柏原良彦：プラズマ溶射皮膜 の残留応力測定、日本機械学會論文集 A 編 68 (673), 2002, 1382-1388.

148）伊藤義康、須山章子、斎藤雄二：ショットコーティングによ りセラミックス表面へ形成されたアルミニウム皮膜の残留応 力特性、日本金属学会誌、66-5 (2002), 445-450.

149) 伊藤義康、須山章子、他：ショットコーティング皮膜の組織 と残留応力、高温学会誌、30 (2004), 154-158.

150) 秋田貢一、戸部省吾; 溶射皮膜の巨視き裂形成臨界歪みに及 ぼす残留応力の影響、材料、53 (2004)-7, 740-745.

151）鈴木賢治、久保貴博、田中啓介、秋庭義明、他：高温酸化し た遮熱コーティングの残留応力分布の解析、材料、54 (2005)7, 679-684.

152) Fumitaka Otsubo, Katsuhiko Kishitake and Toshio Terasaki: Residual Stress Distribution in Thermally Sprayed Self-Fluxing Alloy Coatings, Mater. Trans., 46 (2005)-11, 2473-2477.

$153)$ 大坪文隆、岸武勝彦、寺崎俊夫 : 自溶合金溶射皮膜の残留応 力分布、溶射、43-2 (2006), 42-46.

154）荒井正行、和田英志、岸本喜久雄 : 溶射プロセスに基づくセ ラミック溶射コーティングの残留応力解析、日本機械学會論 文集 A 編 72 (717), 2006, 676-682.

155) 伊藤亭、溝口浩一郎、他：クロミアおよびジルコニア溶射 皮膜に扔ける耐はくり性の非破壊的評価、溶射、37-2 (2000), 61-65.

156) 藤井正浩、吉田 彰、重村貞人、谷 和美、幸 賢司：アルミナ セラミックス溶射ローラの転がり疲れ、日本機械学會論文集 C 編 70 (699), 2004, 3331-3338.

157）鈴木雅人、袖岡 賢、井上貴博：プラズマ溶射により作製した $\mathrm{Al}_{2} \mathrm{O}_{3} / \mathrm{YAG}$ コンポジットコーティングの構造制御と特性、日 本金属学会誌、69-1 (2005), 23-30.

158）荒井雅嗣、有働竜二郎、古瀬宗雄：アルミニウム表面に形成 したアルミナ溶射膜の強度評価、日本機械学會論文集 $\mathrm{A}$ 編 72 (717), 2006, 691-696.

159) 藤井 正浩、吉田 彰、石丸 純、重村貞人、谷 和美：セラミッ クス溶射ローラの転がり疲れに及ぼす溶射皮膜厚さの影響、 日本機械学會論文集 C 編 72 (716), 2006, 1354-1360.

160）荒巻徹、青野雄太、野口博司、宮地真也、立川俊洋、陳 新衛、 茅本隆司：アルミナ溶射皮膜の強度評価: 第 1 報、残留応力 制御法の提案、日本機械学會論文集 A 編 74 (741), 2008, 637646.

161) 岡田博成、植松美彦、戸梶惠郎、小林圭史、原田良夫 : 高速 フレーム溶射およびプラズマ溶射したアルミナ被覆ステンレ 又鋼の疲労挙動、日本機械学會論文集 A 編 75 (749), 2009, 8792.
162）荒巻 徹、濱田 繁、野口博司、宮地真也、立川俊洋、巽 新、 茅本隆司："アルミナ溶射皮膜の強度評価: 第 2 報、き裂の 干渉判定条件及びき裂形状補正法の提案 "、日本機械学會論 文集 A 編 75 (755), 2009, 845-854.

163) 荒巻 徹、濱田 繁、野口博司、宮地真也、立川俊洋、巽 新、 茅本隆司："アルミナ溶射皮膜の強度評価 : 第 3 報、き裂干 涉を考慮した破壊強度安全設計法の提案 "、日本機械学會論 文集 A 編 75 (755), 2009, 855-865.

164）荒巻 徹、濱田 繁、野口博司、宮地真也、立川俊洋、巽 新、 茅本隆司：アルミナ溶射皮膜の強度評価 : 第 4 報、機械的負 荷に対する溶射構造体の強度検討、日本機械学會論文集 $\mathrm{A}$ 編 75 (756), 2009, 1097-1105.

165) 荒巻 徹、野口博司、濱田 繁、宮地真也、立川俊洋、巽 新、 茅本隆司：アルミナ溶射皮膜の強度評価 : 第 5 報、熱負荷に 対する溶射構造体の強度検討、日本機械学會論文集 A 編 75 (757), 2009, 1177-1186.

166）吳 定錫、小茂鳥 潤、清水真佐男：再溶融処理を施した Co 基 自溶合金材料の疲労強度と破壊機構、溶射、37-2 (2000), 166174.

167) 吳 定錫、小茂鳥 潤、清水真佐男: 異なる界面強度を有する Co 基自溶合金材料の疲労特性、溶射、38-2 (2001), 65-72.

168）脇裕之、小倉敬二、西川出、長沼博貴、西井雅宏：ジルコニ ア溶射被覆 SUS304 鋼の高温疲労過程と表面ひずみ挙動、日 本機械学會論文集 A 編 67 (659), 2001, 1148-1154.

169) 王 栄光、木戸光夫、片山剛之丞、他：アルミナ皮膜の高温下 での疲労変形・破壊挙動、溶射、40-1 (2003), 1-8.

170) 曙 紘之、西森久宣、小茂鳥潤：長時間再溶融処理を施した $\mathrm{Ni}$ 基自溶合金溶射部材の疲労特性に及ぼす皮膜厚さの影響、 溶射、42-1 (2005),12-16.

171) 木戸光夫、新原美子、徳田太郎、王 栄光、他：セラミック溶 射材の静荷重下および繰り返し荷重下での表面ひずみと剥離 生成、溶射、43-3 (2006), 73-78.

172) Yoshiko Shinhara, Rongguang Wang, Tarou Tokuda, Mitsuo Kido, Yoshio Harada and Shinji Wada: "Surface Strain Measurement of Thermally Sprayed Ceramics Coatings under Static and Cyclic Loadings and Its Application to Detection of Delamination", Mater. Trans., 48 (2007)-4, 769-774.

173）新原美子、大谷幸三、徳田太郎、木戸光夫、他：セラミック スを被覆した溶射材の常温引張荷重下抢よび熱サイクル下に おけるはく離挙動、溶射、45-4 (2008), 101-106.

174）新原美子、鈴村文寬、徳田太郎、木戸光夫：熱衝撃を受けた ジルコニア溶射材の定荷重下での表面ひずみと損傷評価、溶 射、46-2 (2009), 36-42.

175）須之内辰憲、長 秀雄、小川武史、小林圭史：WC-Co 焼結材 および溶射材の疲労亀裂進展特性の評価、材料、58 (2009)-12, 1037-1043.

176）富田友樹、高谷泰之、谷 和美、原田良夫：VPS 法ならびに $\mathrm{HVOF}$ 法で作製した $\mathrm{Cr}_{3} \mathrm{C}_{2}-\mathrm{NiCr}$ サーメット溶射皮膜の硬さと ミクロ組織、高温学会誌、26 (2000), 248-253.

177) Byoung Hee Kim and Dong Soo Suhr: Characteristics of SprayDried WC-17 mass\%Co Composite Powder Part 1: Effect of Heating, Mater. Trans., 42 (2001)-3, 491-495. 
178）園家啓嗣、李長久、紀 崗昌：HVOF 溶射による $\mathrm{Cr}_{3} \mathrm{C}_{2}-\mathrm{NiCr}$ 皮膜の組織構造と物性との相関性、溶接学会論文集、21-1 (2003), 109-115.

179) 李 成為、加藤昌彦、他：高圧高速フレーム溶射 WC-Co 皮膜 の剥離強度に及ぼす基材脱炭層の影響、材料、53 (2004)-3, 313-320.

180) 李 成為、加藤昌彦、他: 高圧高速フレーム溶射 WC-Co 皮 膜の剥離強度に及ぼすころがり接触疲労の影響、材料、 53 (2004)-8, 862-869.

181）木戸光夫、竹田睦、他：WC サーメット溶射した軟鋼の腐食 疲労破壊挙動、材料、53 (2004)-11, 1228-1233.

182 ) 金子堅司、大森明、平石豊太郎：WC-12Co 溶射被膜の I 及 びIII の混合モード下に扔ける破壊強度に関する研究、日本 機械学會論文集 A 編 70 (695), 2004, 920-927.

183）園家啓嗣、宮沢裕幸：耐熱性及び高温酸化性の優れた溶射技 術の考察、鉄と鋼、91-2 (2005), 259-264.

184) 李 成為、章 博、加藤昌彦、他：高圧高速フレーム溶射 WC-Co 皮膜の表面および界面損傷に及ぼす繰り返しすべり 摩擦の影響、材料、55 (2006)-12,1088-1094.

185）山田基宏、和田浩孝、佐藤憲徳、福本昌弘、他：低圧コール ドスプレー法による銅皮膜の作製と評価、溶接学会論文集、 24-4 (2006), 548-552.

186）伊藤義康、須山彰子、布施俊明：コールドスプレーで作製さ れたアルミニウム皮膜の機械的特性、材料、56 (2007)-6, 550555 .

187）伊藤義康、須山彰子：コールドスプレーで作製されたアルミ 二ウム皮膜の微構造と熱的. 電気的特性、材料、56 (2007)-11, 757-763.

188）伊藤義康、須山彰子、深沼博隆：コールドスプレーで作製さ れた銅皮膜の微構造評価、材料、57 (2008)-8, 832-836.

189) 天尾 聡、市川裕士、小川和洋、深沼博隆：コールドスプレー 法による銅粒子の成膜及びその特性評価、溶射 46-1 (2009), $1-5$

190) Masahiro Fukumoto, Hiroki Terada, Masahiro Mashiko, Kazunori Sato, Motohiro Yamada and Eiji Yamaguchi : Deposition of Copper Fine Particle by Cold Spray Process, Mater. Trans., 50 (2009)-6, 1482-1488.

191）森 敏彦、広田健治、小林鑑明、助田直史：インプラントモデ ル材へのバイオセラミックスの傾斜機能溶射、日本機械学會 論文集 C 編 67(660), 2001, 2686-2691.

192) A.Afshar, M. Ghobani, M.R.Saeri: “Eng. プラズマ溶射によるハ イドロオキシアパタイトコーティング膜表面のカルシウムイ オン無含有 SBF での組織・構造変化"、日本セラミックス協 会学術論文誌、112-2 (2004), 77-81.

193) Chung-Wei Yang, Tzer-Min Lee, Truan-Sheng Lui and Edward Chang: "A Comparison of the Microstructural Feature and Bonding Strength of Plasma-Sprayed Hydroxyapatite Coatings with Hydrothermal and Vacuum Post-Heat Treatment", Mater. Trans., 46 (2005)-3, 709-715.

194) Kensuke Kuroda, Shinji Nakamoto, Ryoichi Ichino, Masazumi Okido and Robert M. Pilliar: Hydroxyapatite Coatings on a 3D Porous Surface Using Thermal Substrate Method, Mater. Trans.,
46(2005)-7, 1633-1635.

195) Kyeong Ho Baik: "Microstructural Evolution and Tensile Properties of Ti-Al-V Alloys Manufactured by Plasma Spraying and Subsequent Vacuum Hot Pressing", Mater. Trans, 47 (2006)-4, 1198-1203.

196) Kyeong Ho Baik: Tensile Failure Behavior of SiC/Ti-6Al-4V Composites Manufactured by Plasma Spraying Route, Mater. Trans., 47 (2006)-11, 2815-2820.

197) Chung-Wei Yang and Truan-Sheng Lui: Effect of Crystallization on the Bonding Strength and Failures of Plasma-Sprayed Hydroxyapatite, Mater. Trans., 48 (2007)-2, 211-218.

198) Yuji Ichikawa, Sophie Barradas, François Borit, Vincent Guipont, Michel Jeandin, Mariette Nivard, Laurent Berthe, Kazuhiro Ogawa and Tetsuo Shoji: Evaluation of Adhesive Strength of ThermalSprayed Hydroxyapatite Coatings Using the LAser Shock Adhesion Test (LASAT), Mater. Trans., 48 (2007)-4, 793-798.

199) 塗谷紘宣、鈴木紹夫、石川量大、北村義治： Zn, Al および $\mathrm{Zn}-\mathrm{Al}$ 合金溶射皮膜の耐候性、材料と環境、51-9 (2002), 404409.

200) Takeshi Kobayashi, Toru Maruyama and Masatoshi Kano: Characterization of Pure Aluminum and Zinc Sprayed Coatings Produced by Flame Spraying, Mater. Trans., 44 (2003)-12, 27112717.

201) Toru Maruyama, Takeshi Kobayashi and Masatoshi Kano: A Spray Coating and Its Mechanical Properties of Al-Si-Zn Alloy Produced by the Spray Forming Process, Mater. Trans., 47 (2006)-7, 18531858.

202）園家啓嗣：粗面化処理を省略できる $\mathrm{Zn} / \mathrm{Al}$ 溶射技術の評価、 鉄と鋼、92-9 (2006), 567-571.

203) 村上健児：アルミニウム $-\mathrm{X}$ (X=銅、亜鉛) 溶射皮膜及び亜鉛 溶射皮膜の海水中に扔ける防食・防污特性と皮膜の構造変化、 溶射、46-2 (2009), 43-47.

204）塗谷紘宣、島 貢、鈴木紹夫、石川量大、他：溶射皮膜上に塗 布した重防食皮膜の耐久性、材料と環境、58-2 (2009), 64-70.

205) 伊藤義康、安藤秀康、須山彰子：アルミニウム溶射皮膜の微 構造と機械的特性、材料、49 (2000)-1, 51-55.

206) 鈴木雅人：プラズマ溶射 $\mathrm{Al}_{2} \mathrm{O}_{3} / \mathrm{YAG}$ 複合皮膜の微細構造、高 温学会誌、28 (2002), 258-264.

207) 村上健児、松本弘司、他：ニッケル溶射皮膜の構造、機械的 性質抒よび熱伝導率、高温学会誌、30 (2004), 336-341.

208）村上健児、藤田直也、他：アーク溶射された銅の酸化と皮膜 構造、高温学会誌、32 (2006), 321-328.

209) 安藤孝志、伊藤伸夫、戸越健一郎、原田良夫：NAS 電池用ア ルミニウム格納容器内壁に施工した高 $\mathrm{Cr}-\mathrm{Fe}$ 合金プラズマ溶 射皮膜の貫通気孔の測定、日本金属学会誌、71-1 (2007), 9095.

210) 大森 明、荻野邦彦、他： $\mathrm{Cr}_{3} \mathrm{C}_{2}-\mathrm{NiCr}$ 皮膜のキャビテーショ ン損傷に及ぼす溶射法掞よび熱処理の影響、高温学会誌、26 (2000), 254-257.

211）水野宏昭、大澤悟、五日市 剛：HVOF 溶射したWCサーメッ 卜溶射皮膜のキャビテーションエロージョン特性に及ぼす影 響因子、溶射、41-3 (2004), 103-108. 
212) 荻野邦彦、大森明、沖幸男、森本純司：アルミナ溶射皮膜 のキャビテーションエロージョン特性に及ぼす皮膜構造の影 響、高温学会誌、30 (2004), 270-278.

213) 谷和美、植松 進、吉岡 勝、高畠 剛、難波吉雄、石原泰明、 三嶋孝洋、川並康剛：耐キャビテーション壊食性を有する高 機能溶射皮膜の開発、高温学会誌、35 (2009), 301-307.

214) 安岡淳一、大森明：アナターゼ型 $\mathrm{TiO}_{2}$ ナノ粒子造粒粉末を 適用した光触媒 $\mathrm{TiO}_{2}$ 溶射皮膜の相変態挙動と粒子成長制御、 高温学会誌、30 (2004), 322-329.

215) Chang-Jiu Li, Guan-Jun Yang, Yu-Yue Wang, Cheng-Xin Li, FuXing Ye and Akira Ohmori, Phase Formation during Deposition of $\mathrm{TiO}_{2}$ Coatings through High Velocity Oxy-Fuel Spraying, Mater. Trans., 47 (2006)-7, 1690-1696.

216) Fuxing YE, AkiraOHMORI, et.al: Structure and Photocatalytic Performance of $\mathrm{TiO}_{2}-\mathrm{FeTiO}_{3}$ Coatings Ptepared by Plasma Spray Technique, 高温学会誌、33 (2007), 300-305.

217）上野和夫、袖岡 賢、鈴木正人、他：雾囲気制御プラズマ溶射 により形成された $5 \% \mathrm{Co}$ 添加 $\mathrm{FeSi}_{2}$ 熱電素子の物性、溶射、 37-3 (2000), 115-122.

218) Cheng-Xin Li, Min Gao, Chang-Jiu Li, Wei Zhou, Guan-Jun Yang and Yu-Yue Wang, Characterization of the Microstructure and Electrical Conductivity of Plasma-Sprayed $\mathrm{La}_{0.5} \mathrm{Sr}_{0.5} \mathrm{CoO}_{3}$ Coating, Mater. Trans., 47 (2006)-7, pp.1654-1657.

219）植松 進、石崎祥希、他：レーザー再溶融処理した反応性 La$\mathrm{SrTiO}_{3}$ プラズマ溶射皮膜の構造とその特性評価、高温学会誌、 33 (2007), 319-324.

220）伊藤英信、二俣正美、他：廃乾電池焙焼粉末を用いて作製し た溶射皮膜の感湿特性、高温学会誌、29 (2003), 111-114.

221）二俣正美、星野泰孝、他：廃乾電池焙焼粉末を用いて作製し た溶射皮膜の親水特性 - 親水性発現機構の検討 - 、高温学会 誌、31 (2005),160-165.

222）二俣正美、中西喜美雄、他：廃乾電池焙焼粉末を用いて作製 した溶射皮膜の親水特性 - 蒸発現象と伝熱促進効果の検討 - 、高温学会誌、31 (2005),347-351.

223) Hongwei Yang, Weiling Luan and Shan-Tung Tu: Corrosion Behavior and Thermal Conductivity of Plasma Sprayed $\mathrm{AlN} / \mathrm{Al}_{2} \mathrm{O}_{3}$ Coating, Mater. Trans., 47 (2006)-7, 1649-1653.

224) Junya Kitamura, Hiroaki Mizuno, Nobuaki Kato and Isao Aoki: Plasma-Erosion Properties of Ceramic Coating Prepared by Plasma Spraying, Mater. Trans., 47 (2006)-7, 1677-1683.

225）森 広行、中西和之、太刀川英男：高 $\mathrm{Si}-\mathrm{Al}$ 合金溶射皮膜の組 織と摩擦摩耗特性、日本金属学会誌、65, No8 (2001), 707-713.

226) Meigin Shi, Fujimasa Miyazawa, Shogo Tobe and T. A. Stolarski: The Friction and Wear Properties of PTFE Composite-Thermal Spray Metallic Binary Coatings, Mater. Trans., 46 (2005)-1, 84-87.

227) 足立振一郎、藤田直哉、花立有功：Ti のプラズマ溶射におけ る酸化と窒化反応に関する考察、溶射、37-2 (2000), 123-129.

228）園家啓嗣：耐摩耗性溶射皮膜のブラストエロージョン特性、 鉄と鋼、86-6 (2000), 388-395.

229）新見彰夫、川村昌志、宇野兵衛：セラミック溶射皮膜中気孔 率と皮膜熱的特性の関係、溶射、38-1 (2001), 17-22.

230) Keisuke Uenishi, Minoru Murase and Kojiro F. Kobayashi: Rapid
Solidification of Ti- 25 mol\%Al Alloy by Plasma Spraying, Mater. Trans., 42 (2001)-2, 269-27.

231) 岩澤誠之、竹本幹男：フレーム溶射アルミニウムおよびアル ミニウム合金の弾性特性の異方性、溶射、38-3 (2001), 134142 .

232) 中山 勝：線爆溶射法による Ni-P/SUS304 複合溶射皮膜の皮膜 特性、溶射、42-3 (2005), 112-116.

233) 清水保雄、A. デバセナパティ、榊 和彦、他：アルミナ皮膜 の溶射効率に及ぼす高速フレーム溶射ガンのノズル形状の影 響、溶射、37-1 (2000), 11-19

234) 佐々木光正 : プラズマ溶射装置、高温学会誌、28 (2002), 253257.

235) 中森正治、相坂隆行、高橋 智、他：水プラズマ溶射と HVOF 溶射による新しい TBC コーティング方法の開発、材料と環境、 52-12 (2003), 650-655

236) 大崎 堅、小林 明、他 : 交差電極型プラズマ溶射ガンの Ti-Al 傾斜構造膜作製への応用、高温学会誌、29 (2003), 235-240.

237) J. L I ,G. BAI, et. al: Double Anodes Plasma Spraying, 高温学会 誌、29 (2003), 230-234.

238）山田基宏、中村 元、福本昌宏、安井利明、他：反応性 RF プ ラズマ溶射による窒化アルミニウム皮膜の創製、溶接学会論 文集、23-1 (2005), 143-149

239) 福本昌宏、中村 元、山田基宏、安井利明 : 反応性 RF プラズ マ溶射による金属基材上への窒化アルミニウム皮膜の作製、 溶接学会論文集、23-4 (2005), 608-612

240）榊原紀幸、真鍋幸男、広本悦己、小林泰幸：雾囲気制御法に よる高品質溶射皮膜形成技術の開発、溶接学会論文集、24-2 (2006), 181-186.

241) Sang-Hoon Lee and Kazuyuki Hokamoto: WC/Co Coating on a Mild Steel Substrate through Underwater Shock Compaction Using a Self Combustible Material Layer (WC/Co Coating through Underwater Shock Compaction), Mater. Trans., 48 (2007)-1, 80-83.

242) 野田佳雅、佐藤 晃、戸部省吾、斉藤政人、他：真空アーク 処理を用いた高密着強度溶射皮膜シリンダーライナーの開発、 溶射、45-3 (2008), 74-79.

243) 野田佳雅、山根正明、戸部省吾、塚田智史、他：真空アーク 処理による TBC の長寿命化、溶射、45-4 (2008), 95-100.

244) J. MORIMOTO, T. OZAKI, et.al: Formation of Ni-based Self Fluxing Layers with Using Direct Diode Laser, 高温学会誌、35 (2009), 314-319.

245) Yasunori TANAKA and Masahiro FUKUMOTO: Effects of Solidification and Wetting on Flattening Behavior of Thermal Sprayed Ceramic Particles, 溶接学会論文集、18-1 (2000), 26-32.

246）沖幸男：プラズマ溶射スプレーパターン上のスプラット形態 の解析、溶射 38-1 (2001), 23-27.

247) TANAKA Yasunori and FUKUMOTO Masahiro: Effect of Spray Distance on Velocity, Temperature and Flattening Behavior of Sprayed Ceramic Particles, 溶接学会論文集、19-3 (2001), 440445 .

248）田中泰徳、川瀬良一、他：プラスティック溶射粒子の扁平形 態と密着強度の相関性、高温学会誌、27 (2001), 280-285.

249) TANAKA Yasunori, NAKASHIMA Masaya and FUKUMOTO 
Masahiro: Effect of Substrate Surface Condition on Flattening Behavior of Thermal Sprayed Ceramic Particles, 溶接学会論文集、 20-2 (2002), 317-321.

250) 田中泰徳、川瀬良一、他：プラスティック溶射粒子の扁平挙 動に対する模擬溶射装置による影響因子の検討、高温学会誌、 28 (2002), 289-294.

251) 福本昌宏、扇谷一慶、椎葉昌洋、安井利明 : 溶射粒子偏平形 態遷移に及ぼす基材加熱の影響解明、溶接学会論文集、22-3 (2004), 398-402.

252）福本昌宏、田部心有、山田基宏、山口英二：コールドスプ レー法による銅粒子堆積機構の解明、溶接学会論文集、2442006), 537-541.

253) 安藤孝志、伊藤伸夫、戸越健一郎、原田良夫：高 $\mathrm{Cr}-\mathrm{Fe}$ 合金 プラズマ溶射皮膜の扁平挙動と NAS 電池用 $\mathrm{Al}$ 円筒容器内壁 面への皮膜の密着性に及ぼす予熱温度の影響、日本金属学会 誌、71-3 (2007), 354-360.

254) Y.-Y. Wang, C.-J. Li, K. Kusumoto and G.-J. Yang: Deposition Behaviors of Solid Phases in Liquid-Solid Two-Phase Particles in High Velocity Oxy-Fuel Spraying, Mater. Trans., 47 (2006)-7, 1684-1689.

255) 村上健児、藤田直也、他：鉄粉末の大気中プラズマ溶射で得 られた粉末粒子、スプラットおよび皮膜の組織、高温学会誌、 27 (2001), 250-255.

256) 村上健児、松本弘司、他：ニッケル溶射皮膜の構造、機械的 性質および熱伝導率、高温学会誌、30 (2004), 336-341.

257) 村上健児、藤田直也、他：アーク溶射された銅の酸化と皮膜 構造、高温学会誌、32 (2006), 321-328.

258) 佐藤岳彦、オレグ・ソロネンコ、西山秀哉: 数值シミュレーショ ンによるセラミック溶射プロセスの評価、溶射、40-1 (2003), 9-13.

259) Oleg Pavlovich Solonenko, Mikhalchenko Alexandr Anatol' yevich, Kartaev Evgenii Vladimirovich, Bondar' Mariya Petrovna, Kazuhiro Ogawa, Tetsuo Shoji and Masatoshi Tanno: Theoretical Modeling and Experimental Study of Thermal Barrier Coatings, Mater. Trans., 44 (2003)-11, 2311-2321.

260) 片野田 洋、山本秀樹、松岡武司、松尾一泰：高速フレーム 溶射ガンの流動特性に関する気体力学的研究: 第 1 報、貯気 圧とバレル長さの影響、日本機械学會論文集 B 編 72 (714), 2006, 271-278.

261) 片野田 洋: 高速フレーム溶射ガン内のガスと粒子の挙動に及 ぼす管摩擦、冷却、ノズル形状の影響に関する一次元解析、 溶射、43-3 (2006), 79-85.

262) 片野田 洋、福原 稔、飯野直子：溶射粒子の加速原理に関す る理論的考察（第一報 運動方程式の近似解に基づく粒子の加 速原理)、溶射、43-4 (2006), 108-114.

263) Hiroshi Katanoda and Kazuyasu Matsuo: Gasdynamic Simulation of Aerosol Deposition Method, Mater. Trans., 47(2006)-7, 16201625 .

264) Kensuke Yokoyama, Makoto Watanabe, Seiji Kuroda, Yoshihiko Gotoh, Tobias Schmidt and Frank Gärtner: Simulation of Solid Particle Impact Behavior for Spray Processes, Mater. Trans., 47 (2006)-7, 1697-1702.
265) Jingwei Wu, Hongyuan Fang, Sanghoon Yoon, Changhee Lee and HyungJun Kim: Critical Velocities for High Speed Particle Deposition in Kinetic Sprayin, Mater. Trans., 47 (2006)-7, 17231727.

266) Hiroshi Katanoda: Quasi-One-Dimensional Analysis of the Effects of Pipe Friction, Cooling and Nozzle Geometry on Gas/Particle Flows in HVOF Thermal Spray Gun, Mater. Trans., 47 (2006)-11, 2791-2797.

267) 片野田 洋、福原 稔、飯野直子、松尾一泰：超音速自由噴流 の半実験式を用いた高速フレーム溶射の粒子挙動の理論解 析、溶射、44-1 (2007), 1-6.

268) Hiroshi Katanoda, Minoru Fukuhara and Naoko Iino: Numerical Simulation on Impact Velocity of Ceramic Particles Propelled by Supersonic Nitrogen Gas Flow in Vacuum Chamber, Mater. Trans., 48 (2007)-6, 1463-1468.

269）恩地智史、小川和洋、久保百司：分子動力学法によるコール ドスプレーで施工した $\mathrm{Ni}$ 基超合金粒子の付着メカニズムの 基礎的検討、溶射、46-4 (2009), 116-120.

270) 高 三徳、中佐啓治郎、加藤昌彦 : 等二軸引張りを受ける溶射 皮膜の割れ形態のシミュレーション、日本機械学會論文集 $\mathrm{A}$ 編 66 (641), 2000, 122-130.

271）窪堀俊文、生田稔郎：ブラスト加工によるピーニング効果、 溶射、37-1 (2000), 1-5

272) 天田重康、三田浩史：ブラスト粗面のフラクタル次元による 評価、溶射、37-2 (2000), 43-52

273）大坪文隆、秋山哲也、岸武勝彦、寺崎俊夫：ブラス卜処理に よるオーステナイトステンレス鋼の耐食性変化、溶射、39-3 (2002), 108-112.

274）丸山 薰、小林 武：溶射基材の表面状態と溶射皮膜の密着性、 溶射、39-4 (2002), 144-149

275）窪堀俊文、山本裕也、生田稔郎：ブラスト加工に関する研究 - 試験片温度がブラスト加工に及ぼす影響 - 、溶射、42-1 (2005), $1-5$.

276）窪堀俊文、前田崇行、乾 保之、生田稔郎：混合ブラスト材が ブラスト加工に及ぼす影響、溶射、43-3 (2006), 86-91.

277) 窪堀俊文、前田崇行、乾 保之、生田稳郎：基材の傾斜がブラ ス卜加工に及ぼす影響、溶射、43-4 (2006), 115-121.

278）安藤孝志、原田良夫：NAS 電池用 $\mathrm{Al}$ 円筒容器内面への溶射 前処理としての量産用ブラスト加工条件の最適化、高温学会 誌、32 (2006), 336-342.

279）窪堀俊文、伊藤 亨、他：ブラスト加工が基材に及ぼす衝突圧 力、ピーニング効果抢よび除去加工、高温学会誌、33 (2007), 306-312.

280) 窐堀俊文、倉本賢司、他：ブラスト材の耐久性に関する研究、 高温学会誌、35 (2009), 308-313.

281) 小幡文雄、佐藤 紀、古屋 諭：YAG レーザによる難削材料 の加熱旋削加工に関する研究 : 第 3 報、ステライト自溶合金 溶射皮膜の局所加熱旋削加工、日本機械学會論文集 $\mathrm{C}$ 編 66 (646), 2000, 2047-2053.

282）桑嶋孝幸、高橋畿久雄、大森明：HVOF-YAG レーザーハイ ブリッド溶射による WC-Co 系皮膜の性状、高温学会誌、26 (2000), 258-264 
283）桑嶋孝幸、高橋畿久雄、大森明：HVOF-YAG ハイブリッド 溶射条件の WC-Co 皮膜性状への影響、高温学会誌、27 (2001), 269-273.

284) 桑嶋孝幸、高橋幾久雄、富田友樹、大森明：レーザー同時照 射による高速フレーム $\mathrm{Cr}_{3} \mathrm{C}_{2}-\mathrm{NiCr}$ 溶射皮膜の改質効果、日本 金属学会誌、66-9 (2002), 444-447.

285）桑嶋孝幸、高橋畿久雄、大森明：高速フレーム溶射スプラッ ト形成に及ぼすレーザー同時照射の影響とその皮膜形成メカ ニズム、高温学会誌、29 (2003), 222-229.

286) 丹野昌利、小川和洋、庄司哲雄、大森明、他：レーザー再 溶融処理による熱遮蔽コーティングの界面強度改善、溶射、 40-4 (2003), 159-165.

287) 桑嶋孝幸、高橋幾久雄、富田友樹、大森明：高速フレーム $\mathrm{Cr}_{3} \mathrm{C}_{2}-\mathrm{NiCr}$ 溶射皮膜組織へのレーザー処理条件の影響、日本 金属学会誌、68-2 (2004), 118-121.

288) Takayuki Kuwashima, Ikuo Takahashi, Tomoki Tomita and Akira Ohmori: Effect of Simultaneous Laser Irradiation on a $\mathrm{Cr}_{3} \mathrm{C}_{2}$-NiCr Coating Produced by High-Velocity Oxy-Fuel Spraying Process, Mater. Trans., 45 (2004)-6, 1864-1868.

289) 阿部信行、森本純司、塚本雅裕、他：半導体レーザー再溶融

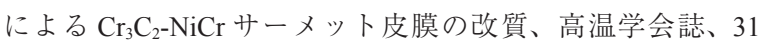
(2005), 352-356.

290）植松 進、石崎祥希、他：レーザー再溶融処理した反応性 La$\mathrm{SrTiO}_{3}$ プラズマ溶射皮膜の構造とその特性評価、高温学会誌、 33 (2007), 319-324.

291) Byoung Hee Kim and Dong Soo Suhr: Characteristics of HVOFSprayed $\mathrm{Cr}_{3} \mathrm{C}_{2}$ (20mass\%NiCr) Coatings Part 2: Effect of Heat Treatment of the Coatings, Mater. Trans., 42 (2001)-5, 870-875.

292) Masato Suzuki, Satoshi Sodeoka and Takahiro Inoue: Structure Control of Plasma Sprayed Zircon Coating by Substrate Preheating and Post Heat Treatment Mater. Trans., 46 (2005)-3, 669-674.

293) Chung-Wei Yang, Tzer-Min Lee, Truan-Sheng Lui and Edward Chang: "A Comparison of the Microstructural Feature and Bonding Strength of Plasma-Sprayed Hydroxyapatite Coatings with Hydrothermal and Vacuum Post-Heat Treatment", Mater. Trans., 46 (2005)-3, 709-715.

294) Hongbo Guo, Hideyuki Murakami and Seiji Kuroda: Effects of Heat Treatment on Microstructures and Physical Properties of Segmented Thermal Barrier Coatings, Mater. Trans., 46 (2005)-8, 1775-1778.

295) Chun-Cheng Chen and Shinn-Jyh Ding: Effect of Heat Treatment on Characteristics of Plasma Sprayed Hydroxyapatite Coatings, Mater. Trans., 47 (2006)-3, 935-940.

296) Kyeong Ho Baik: "Microstructural Evolution and Tensile Properties of Ti-Al-V Alloys Manufactured by Plasma Spraying and Subsequent Vacuum Hot Pressing", Mater. Trans., 47 (2006)-4, 1198-1203.

297) Takayuki Kuwashima, Hiroshi Horie, Takashi Saitoh, Takahito Takagawa, Takashi Iimura and Tetsuya Sonoda, Effect of Heat Treatment Conditions on Micro Structure of Cast Iron Coatings Sprayed by HVOF Spraying: Mater. Trans., 47 (2006)-7, 16581664.

298) 高橋 智、吉葉正行、原田良夫：プラズマ溶射 TBC システム
の高温酸化特性に及ぼす皮膜後熱処理条件の影響、日本金属 学会誌、71-1 (2007), 47-54.

299）大坪文隆、大原秀樹、岸武勝彦： NiAl 複合粉末溶射皮膜の熱 処理による $\mathrm{Ni}_{3} \mathrm{Al}$ の生成、溶射、44-3 (2007), 83-87.

300) 野田佳雅、佐藤 晃、戸部省吾、原 正行、他：真空アークク リーニング法によるブラスト代替技術および高密着強度 APS 皮膜の開発、溶射、45-2 (2008), 39-44.

301）野田佳雅、佐藤 晃、戸部省吾、斉藤政人、他：真空アーク処 理を用いた高密着強度溶射皮膜シルンダーライナーの開発、 溶射、45-3 (2008), 74-79.

302）野田佳雅、山根正明、戸部省吾、塚田智史、他：真空アーク 処理による TBC の長寿命化、溶射、45-4 (2008), 95-100.

303) Yoshimasa Noda, Akira Sato, Shogo Tobe, Masayuki Hara and Tsuginori Inaba: Development of Alternative Method of Blasting and Ultra-High Adhesive Strength Thermal Spray Coatings by Vacuum Arc Treatment, Mater. Trans, 50 (2009)-4, 825-831.

304) 乾保之、窪堀俊文、生田稔郎：アルミナチタニア系溶射セラ ミックスの研削加工に関する研究、溶射、43-2 (2006), 36-41.

$305)$ 安藤孝志、原田良夫：NAS 電池用プラズマ溶射高 $\mathrm{Cr}-\mathrm{Fe}$ 合金 皮膜の表面研磨技術の開発とその単電池特性、日本金属学会 誌、70-3 (2006), 213-219.

306）周展、白沢秀則、大森明：Mn 系金属融体を浸透 - 焼結処理 したYSZ 溶射皮膜の密着強度と界面形成機構の検討、高温 学会誌、27 (2001), 256-263.

307) 佐藤丈士、後藤 學、前田康晴：チタン板の絞り加工用金型へ の溶射皮膜の適応性評価、日本機械学會論文集 C 編 66 (643), 2000, 1002-1007.

308) 安藤秀康、伊藤義康、西脇 進、今井俊哉 : 溶射アルミニウム 電極の最適化による $\mathrm{ZnO}$ バリス夕素子のエネルギー吸収効 率の向上、材料、49 (2000)-9, 982-987.

309) 福田祐治、川原雄三 : 高速ガス炎溶射した廃棄物発電プラ ント用過熱器管の耐食性評価、日本金属学会誌、66-6 (2002), 576-582.

310) 伊藤義康、安藤秀泰、須山章子、新藤尊彦：プラズマ溶射法 で作製された $\mathrm{Cu}-\mathrm{W}$ 複合コーティングの機械的特性、日本金 属学会誌、65-10 (2001), 929-934

311) 伊藤義康、安藤秀泰、須山章子、新藤尊彦：プラズマ溶射法 で作製された $\mathrm{Cu}-\mathrm{W}$ 複合コーティング皮膜の熱的・電気的的 特性、日本金属学会誌、65-12 (2001), 1108-1112.

312) 伊藤明洋、杉田雄二、桜井茂雄、龟田 純 : ガスタービン動翼 コーティング材の長時間熱時効による機械的特性の変化、材 料、 51 (2002)-12, 1405-1410.

313）緒方隆志、野本明義：ガスタービン動翼材 IN738LC の熱疲 労寿命に及ぼす耐食コーティングの影響、材料、52 (2003)-2, 139-145.

314) 荒井正行、岩田宇一、水津竜夫、谷和美: 縦割れ遮熱コーティ ング材の機能性評価、材料、53 (2004)-8, 862-869.

315) 園家啓嗣、若林 元、戸部省吾、他： $\mathrm{MoSi}_{2}$ 中間層を導入し た熱サイクル特性の優れた遮熱溶射皮膜の開発、溶射、42-4 (2005), 161-166.

316) 荒井正行：発電用ガスタービン燃焼器に施された $\mathrm{TBC}$ の損 傷評価、材料、 57 (2008)-3, 285-291. 
317) 安藤孝志、戸越健一郎、原田良夫：" 長時間運転された電力 貯蔵用 NAS 電池のアルミニウム円筒内壁面に施工された高 $\mathrm{Cr}-\mathrm{Fe}$ 合金プラズマ溶射皮膜の耐硫化腐食性と密着強さ"、日 本金属学会誌、72-8 (2008), 581-586.

318）竹内純一、山崎良、谷和美: 大気プラズマ溶射法を用いた 静電吸着能を有するセラミック皮膜の開発、高温学会誌、34 (2008), 287-292

$319)$ 浜島和雄、石川泰成: $\mathrm{ZrO}_{2} /$ サーメット二層溶射皮膜の剥離

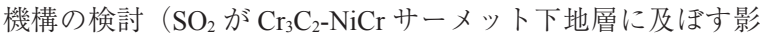
響)、溶射、46-4 (2009), 109-115.

320) 谷和美：最近の溶射技術の適用動向と課題、高温学会誌、29 (2003), 209-216.

321）谷和美、中平晃：わが国における溶射技術／産業の発展と 課題、溶射、44-3 (2007), 96-102.

322）大森明、中平 晃：最新の溶射技術の動向、表面技術誌、59-8 (2008), 484-489.

323）園家啓嗣：溶射技術と各種製品への適用、高温学会誌、35 (2009), 292-294.

324）佐々木光正：プラズマ溶射によるセラミックスを用いた表面 改質、表面技術誌、51-3 (2000), 167-174.

325）原田良夫：高温・耐食コーティングプロセスの現状と将来動 向、まてりあ、40-4 (2001), 316-321.

326）岸武勝彦：耐食・耐摩耗性に優れた鉄基非晶質溶射皮膜の開 発、まてりあ、40-4 (2001), 331-334.

327) 岡崎正和：ガスタービン用 $\mathrm{Ni}$ 基超合金コーティング材の熱 機械的疲労強度と寿命推定、まてりあ、40-4 (2001), 335-339.

328) 吉葉正行：ガスタービン用耐熱・耐食コーティングシステム の複合型損傷解析、まてりあ、40-4 (2001), 340-345.

329）塙隆夫：表面改質による金属の生体適合化・機能化、まてり あ、46-3 (2007), 203-206.

330）林 重成、成田敏夫：耐酸化コーティングと $\mathrm{Ni}$ 基超合金の拡 散と組織、まてりあ、46-3 (2007), 225-228.

331) 谷和美: 耐摩耗表面改質プロセス拉よびその皮膜、日本ガス タービン学会誌、35-5 (2007), 313-319.

332) 高谷泰之: 高硬度溶射皮膜とその耐腐食性、表面技術誌、 59-8 (2008), 520-525.

333）原田良夫：ボイラプラントへ適用した溶射皮膜の防食効果と コロージョンエンジニアリングの重要性、高温学会誌、26 (2000), 226-232.

334) 川原雄三 : 廃棄物発電ボイラにおける高温耐食コーティング の適用と耐久性評価の現状、溶射、38-2 (2001), 73-82.

$335)$ 有川秀行、児島慶亨：ガスタービン用材料の耐熱コーティン グ、表面技術誌、52-2 (2001), 11-19.

336）川原雄三：高効率廃棄物発電ボイラへの高耐久性金属溶射の 適用、まてりあ、40-4 (2001), 346-350.

337）浜谷秀樹、一山靖友：製鉄機械への耐腐食・耐摩耗性溶射皮 膜の展開 - 連続鋳造機用の長辺モールドへの溶射技術の開発 一、まてりあ、40-4 (2001), 351-355.

338）太刀川英男、中西和之、森広行：自動車部品への耐摩耗溶射 技術の適用、まてりあ、40-4 (2001), 356-359.

339) 森 信義: 航空機エンジンへの溶射の適用と課題、高温学会誌、 27 (2001), 232-237.
340）中西和之、太刀川英男、他：自動車への溶射技術の適用、高 温学会誌、27 (2001), 238-243.

341) 森 信義：航空機用ガスタービンコーティング技術、日本ガス タービン学会誌、30-6 (2002), 488-492

342）巟島慶亨、有川秀行：発電用ガスタービンコーティング技術 : 日本ガスタービン学会誌、30-6 (2002), 493-496.

343) 吉岡洋明：コーティングの補修および予防保全技術、日本ガ スタービン学会誌、30-6 (2002), 510-513.

344）金子秀明、鳥越泰治、他：産業用ガスタービン遮熱コーティ ングの信頼性向上技術、日本ガスタービン学会誌、30-6 (2002), 514-518.

345) 久松 暢： $\mathrm{CO}_{2}$ 回収対応クローズドガスタービン用遮熱コー ティングの開発、日本ガスタービン学会誌、30-6 (2002), 519525 .

346）辻野文三 : 大型鉄鋼構造物の長期防錆法の指針 -アーク溶射 によるアルミニウム溶射皮膜 - 、高温学会誌、28 (2002), 247252.

347) 原田良夫：ガスタービン用コーティング技術、日本ガスター ビン学会誌、31-2 (2003), 94-107.

348）森本純司、山田勝弘：ごみ焼却施設腐食環境への溶射技術の 適用と課題、高温学会誌、29 (2003), 217-221.

349) Mineaki MATSUMOTO: Development of Plasma-Sprayed Thermal Barrier Coatings with Low Thermal Conductivity and High Oxidation Resistance (review), J. Ceram. Soc. Jpn, 115 (2007)-1338, 118-123.

350) 児島慶亨：発電用ガスタービンへの溶射技術の適用、表面技 術誌、59-8 (2008), 508-513.

351）安藤孝志、原田良夫：電力貯蔵用ナトリウム・硫黄電池への 溶射技術の適用、表面技術誌、59-8 (2008), 514-519.

352) 松崎祐司、川村昌史：遮熱コーティングの寿命推定、日本ガ スタービン学会誌、30-6 (2002), 497-502.

353) 中山真人: コーティングの損傷機構と評価技術、日本ガスター ビン学会誌、30-6 (2002), 503-509.

354) 伊藤義康、和田国彦：耐熱コーティングの開発動向と性能評 価試験方法の標準化、表面技術誌、59-8 (2008), 501-507.

355) 佐々木光正 : 新溶射プロセスの開発とシステム化、まてりあ、 40-4 (2001), 326-330.

356) 明度 純: 微粒子、超微粒子の衝突固化現象を用いたセラミッ クス薄膜形成技術－エアロゾルデポジション法による低温・ 高速コーティングー、まてりあ、41-7 (2002), 459-466.

357) 小林明：スマートプラズマ溶射システムによる新機能性材料 の創製、表面技術誌、56-11 (2005), 660-664.

358) 榊 和彦：高速フレーム溶射からコールドスプレーへの取り組 みと抱負、溶射、44-3 (2007), 111-113.

359) 安藤康高：溶射技術としての反応性熱プラズマプロセス、溶 射、44-3 (2007), 114-115.

360) 榊 和彦：新しい溶射法コールドスプレーの現状と課題、表面 技術誌、59-8 (2008), 490-494.

361) 和田哲義：高速フレーム (HVOF) 溶射の現状と課題、表面技 術誌、59-8 (2008), 495-500.

362) 吉田豊信:溶射プロセス高度化の要件、まてりあ、40-4 (2001), 322-325. 
363) 福本昌弘：溶射プロセスに対する理解の現状と今後の課題、 溶射、44-3 (2007), 103-110.

364) 納富 啓: 溶射技術の進展と課題、日本機械学會論文集 $\mathrm{A}$ 編 74 (738), 2008, 175-178

365) 米田佗：集じん技術 - 工場における粉じん対策 - 、溶射、 38-4 (2001), 206-212.

366) 廣瀬伸吾、大森明、小泉俊雄: 中小受託加工企業へのアンケー 卜調査で見る溶射業界の現状と将来、溶射、39-4 (2002), 158164 .
367) 廣瀬伸吾、大森 明、北原繁、勝村宗英、他 : 溶射データベー 又一公的機関が構築拈よび運営する中小製造業者のため の溶射技術知識ネットワークシステム 一、溶射、42-1 (2005), 22-28.

368) A. Nakahira : Current Status and Future Prospect of Thermal Spray Coating Applications and Coating Market of Job Shops in Japan, Proc. Int'1 Thermal Spray Conf., 2009, Las Vegas, ASM International, 499-504. 